LAERE

MIDDEL

ODK

\title{
Læremidler og læremiddelbrug i L1 i Danmark
}

\section{Læreres ibrugtagning, didaktisering og redidaktisering af didaktiske, semantiske og funktionelle læremidler i danskundervisningen}

Af Stig Toke Gissel, Bettina Buch, Dorthe Carlsen og Lene Illum Skov

Korrekt citering af denne artikel efter APA-systemet (American Psychological Association System, 7th Edition): Gissel, S. T., Buch, B., Carlsen, D. \& Skov, L. I. (2021). Læremidler og læremiddelbrug i L1 i Danmark. Læreres ibrugtagning, didaktisering og redidaktisering af didaktiske, semantiske og funktionelle læremidler $\mathrm{i}$ danskundervisningen. Learning Tech - Tidsskrift for læremidler, didaktik og teknologi, (3), 80-119. DOI: 10.7146/It.v6i9.124762 
Denne artikel undersøger, hvilke læremidler der anvendes i L1under-visningen i danske 7. klasser, og hvordan læremidlerne bruges i undervisningen. Studiet fokuserer både på didaktiske, semantiske og funktionelle læremidler, hvordan brugen af læremidlerne rammesættes af læreren samt forholdet mellem det intenderede design i de didaktiske læremidler og den aktualiserede undervisning. Artiklens fokus er særligt på, hvordan læreren aktualiserer eller redesigner det intenderede didaktiske design i læremidlerne. Datagrundlaget for undersøgelsen er 25 videoobserverede lektioners danskundervisning fordelt på otte skoler. Et centralt fund er, at de anvendte didaktiske læremidler spænder fra højt didaktiserede læremidler til meget lavt didaktiserede arbejdsark. Lærernes brug af de højt de højt didaktiserede læremidler må typisk karakteriseres som ibrugtagning snarere end redidaktisering, og lærerne didaktiserer sjældent de lavt didaktiserede didaktiske læremidler. Et andet væsentligt fund er, at digitale funktionelle læremidler er på spil i alle cases, men som en selvfølgelighed, der ikke gøres til genstand for rammesætning eller vejledning fra lærerens side.

This article examines which learning materials are used in the L1 teaching in 7 th grades, and how these are being used. The study focuses on didactic, semantic, and functional learning materials, how the use of the materials is framed by the teacher and the relationship between the intended design and the actualized teaching. The focus of the article is on how the teacher actualizes or redesigns the intended didactic design in the learning materials. A key finding is that the didactic learning materials used, range from highly didacticized teaching aids to very low-didacticized worksheets. Teachers' use of highly didacticized learning materials must typically be characterized as adoption rather than adaptation or redidactization, and teachers rarely didacticize low-didacticized learning materials. Another significant finding is that digital functional learning materials are in play in all cases, but is not made the subject of framing by the teacher. 


\section{Læremidler og \\ læremiddelbrug i L1 i Danmark}

\section{Læreres ibrugtagning, didaktisering og redidaktisering af didaktiske, semantiske og funktionelle læremidler i danskundervisningen}

\section{Læremidler i danskfaget}

Der er mange forskellige læremidler i spil i danskundervisningen: Eleverne læser en novelle af Kim Fupz Aakeson, de ser YouTubevideoer, maler billeder, laver en planche af pap eller en ordsky med Wordle, som læreren har fundet via Skoletube. Læremidler kan forstås som midler, som lærere og elever bringer i anvendelse med læring som mål (Hansen \& Skovmand, 2011, s. 19). Man kan vanskeligt forestille sig en undervisning gennemført helt uden læremidler, når man anlægger denne brede definition. Men hvilke typer læremidler anvendes i danskundervisningen og hvordan?

Didaktisk forskning i modersmålsundervisning rummer en stærk tradition for at undersøge læremidler som pædagogiske tekster (Knudsen, 2011), didaktiske læremidler (Hansen \& Carlsen, 2009; Hansen, 2015) eller historiske dokumenter (Sørensen, 2016) ved hjælp af redskaber og modeller, der bygger på tekstanalytiske teorier og tilgange. Det vil sige, at man først og fremmest analyserer læremidler som dokumenter, der består af en flerhed af tegn, tekster, modaliteter, diskurser, genrer og andre designelementer. Man kan derfor beskrive den L1-didaktiske tradition for at forske i læremidler som en tradition fokuseret på læremidlerne som tekster.

En konsekvens af denne tradition er, at man kun i begrænset omfang har undersøgt læremidler som et artefakt i brug. De seneste årtier har enkelte ph.d.-projekter bidraget med mindre casestudier, der giver et indblik i brug af læremidler (Hansen, 2006; Slot, 2010). Desuden har et par større kvantitative undersøgelser suppleret ved at tegne et mere generelt billede af, hvilke typer af læremidler, 
der er mest udbredte og bliver foretrukket af lærerne (Bremholm, Bundsgaard, Fougt, \& Skyggebjerg, 2017; Gissel \& Skovmand, 2018). De enkeltstående kvalitative indblik og de kvantitative overblik peger frem imod et underbelyst område inden for L1-forskningen, nemlig en systematisk undersøgelse af læremidler i brug i L1-undervisningen. Læremidlerne i sig selv tilbyder potentielle undervisningsmuligheder, men lærere kan gennemføre god undervisning med dårlige læremidler - og omvendt. Når vi interesserer os for, hvilken danskundervisning eleverne faktisk modtager, møder og deltager i, er det helt centralt at undersøge læreres brug af læremidler. I denne artikel præsenterer vi de fund, vi har gjort i en empirisk undersøgelse af læreres brug af læremidler i danskundervisningen i Danmark.

\section{Typer af læremidler og didaktiske funktioner}

Læremidler bliver brugt til mange ting. De er multifunktionelle, og de bliver brugt af forskellige aktører fra pædagogisk ledelse, vejledere, lærere og elever til forældre og andre interessenter i skolens omverden. De kan derfor konceptualiseres som eksempelvis et udviklingsværktøj, et undervisningsværktøj, et læringsværktøj, et monitoreringsværktøj og et legitimeringsværktøj (Hansen \& Gissel, 2019). I dette projekt har vi fokuseret på læremidler som undervisningsværktøj. Som den indledende læremiddeldefinition viser, opfattes læremidler grundlæggende som en brugsting og vil derfor analyseres, karakteriseres og vurderes som sådan.

Vi kan overordnet skelne mellem tre typer af læremidler (Hansen, 2010). Typerne adskiller sig ved den funktion, de kan have i undervisningen, og i hvor høj grad eller hvordan de kræver lærerens didaktisering for at være anvendelige som midler til elevers læring. Med didaktisering forstår vi den handling, der gør noget til et læremiddel i forhold til undervisning (Hansen \& Skovmand, 2011).

De tre læremiddeltyper er:

Didaktiske loeremidler er produceret med henblik på at blive anvendt i undervisning. Dette betyder, at producenten har indtænkt den didaktiske brugssituation i læremidlets design og indhold, således at læreren støttes i didaktiske grundfunktioner som målfastsættelse, indholdsvalg, metodisk tilgang, tilrettelæggelse af aktiviteter, organisering og evaluering. Didaktiske læremidler kan derfor potentielt være højt didaktiserede (J. J. Hansen, 2010), idet mange af de didaktiske grundfunktioner operationaliseres i læremidlet. I det omfang en lærer i sin anvendelse af et didaktisk 
læremiddel træffer didaktiske valg og fravalg, som ligger ud over det i læremidlet præsenterede, kan vi tale om lærerens redidaktisering af læremidlet (J. J. Hansen, 2006). Redidaktisering indebærer, at læreren i sit didaktiske design foretager ændringer i forhold til det foreslåede didaktiske design i læremidlet (Hansen \& Skovmand, 2011). Redidaktisering er kun relevant at tale om i forhold til de dele af et didaktisk læremiddel, som er didaktiserede fra producentens side. Når læreren iværksætter didaktiske tiltag på områder, hvor læremidlet ikke er didaktiseret fra producentens hånd, betegner vi det som didaktisering. Når læreren anvender det didaktiske læremiddel i overensstemmelse med det didaktiske design, der kommer til udtryk i læremidlet, taler vi om ibrugtagning.

Semantiske loeremidler er tekster og ting, der ikke er produceret med undervisning for øje, og som har en betydning og funktion i samfundet uafhængigt af undervisningskontekster. Eksempler er en madopskrift, der bruges i hjemkundskab, et digt, der bruges i danskfaget, eller en dokumentarfilm, der bruges i fysikfaget. At tage et semantisk læremiddel i anvendelse i undervisningen kræver didaktisering fra lærerens side; læreren skal identificere, hvilke mål læremidlet kan bidrage til at opfylde, og hvilke aktiviteter eleverne skal udføre for at lære af læremidlet osv.

Funktionelle loeremidler er værktøjer, der faciliterer læring og undervisning ved, at processer i undervisningen bliver mulige, nemmere at udføre eller mere effektive. En kridttavle eller en elektronisk pendant, en lineal eller et tekstbehandlingsprogram er eksempler på funktionelle læremidler. Heller ikke funktionelle læremidler er eksklusivt produceret til undervisningsbrug, og disse kræver også lærerens didaktisering for at fungere hensigtsmæssigt i en didaktisk kontekst.

Læremidler kan undersøges ud fra tre perspektiver, nemlig læremidlerne selv som tekster og artefakter, hvor man ser på læremidlets potentielle didaktiske potentiale, brugen af læremidler, hvor et didaktisk potentiale aktualiseres af læreren eller eleverne, samt læremidlernes virkning forstået som det realiserede potentiale, dvs. det eleverne får ud af at bruge læremidlet i undervisningen (Bundsgaard \& Hansen, 2011).

Som tidligere nævnt har der i læremiddelforskningen primært være fokus på læremidlerne som artefakter (Gissel \& Buch, 2020; Knudsen, 2011), hvor læremidlets potentielle læringspotentiale undersøges. I en konkret undervisnings- og læringssituation aktualiseres 
det didaktiske læremiddels potentiale i et eller andet omfang. Som Bundsgaard og Hansen (2011) skriver, vil lærere og elever i den aktuelle situation med brug af et læremiddel bruge det mere eller mindre som forventet i læremidlet, ligesom de kan inddrage andre læremidler. Denne aktualisering kan studeres gennem observation af undervisning med læremidlet samt interviews med lærere og elever. Endelig kan et læremiddel have et eksplicit eller implicit forventet udkomme. Læringspotentialet er en del af analysen af selve læremidlet, mens det realiserede læringsudbytte må måles gennem test, observation eller interviews.

De tre læremiddeltypers forskellige karakteristika betyder, at undersøgelsen af de forskellige typer vil interessere sig for forskellige aspekter af brugen - afhængigt af typen. Ved de didaktiske læremidler vil den tekstanalytiske læremiddelanalyse kunne afdække, hvilket (fag)didaktisk potentiale der ligger i læremidlet, og undersøgelsen af brugen af læremidlet kan fokusere på sammenhængen eller diskrepansen mellem de didaktiske intentioner, der ligger i læremidlet og lærerens aktualiserede didaktiske design. Brugen kan spænde fra simpel ibrugtagning, hvor læremidlet anvendes helt i overensstemmelse med lærervejledningen og det didaktiske design beskrevet i læremidlet, til redidaktisering, hvor læreren iværksætter didaktiske tiltag som ligger ud over det læremidlet beskriver. Ved semantiske og funktionelle læremidler er spillepladen for anvendelsen som udgangspunkt større og mindre forudsigelig, idet læreren ikke kan støtte sig til en producents didaktisering, men selv må udvikle et didaktisk design og omsætte dette til handling.

\section{Forskning om læremidler i didaktikken}

Læremidler spiller en væsentlig rolle i forhold til undervisning, idet de kan betragtes som en repræsentation af et fags indhold og arbejdsformer (Valverde, Bianchi, Wolfe, Schmidt \& Houang, 2002). Denne anskuelse afspejles i Tri-Partite-modellen fra International Association for the Evaluation of Educational Achievement (IEA) (Houang \& Schmidt, 2008), hvor curriculum defineres som lagdelt: det intenderede niveau, hvor et fags indhold udtrykkes politisk, $\mathrm{i}$ Danmark gennem læreplanerne for fagrækken, Fælles Mål (Børne- og Undervisningsministeriet, 2019), det implementerede niveau, som er den undervisning, der konkret finder sted, og det opnåede niveau, som omhandler, hvad eleverne rent faktisk har lært. Læremidler betragtes som artefakter, der er med til at oversætte curriculum til konkret undervisning, og de kan siges at bygge bro mellem curriculum og den faktiske undervisning, som: “... links between the ideas present in the intended curriculum and the very different world of 
classrooms" (Valverde, Bianchi, Wolfe, Schmidt \& Houang, 2002, s. 9). Anskuet på denne måde bliver læremidler meget vigtige, fordi de udgør et væsentligt element i oversættelsen mellem et intenderet fag (i læreplanen) og det realiserede, faktiske fag i skolen (Bundsgaard, Buch \& Fougt, 2017).

Inden for en didaktisk tradition (i modsætning til en curriculum-tradition) lægges vægt ikke blot på læremidlets oversættelse af curriculum. I den kontinentale, didaktiske tradition er læreren den, der reelt transformerer læreplanens intentioner til didaktisk meningsfuld undervisning - og i denne transformationsproces spiller læremidler en væsentlig rolle. Paul Heimann definerer som en af de første læremidler som et selvstændigt element i almendidaktikken (Hansen, 2006, s. 245), og Hartmut Hacker (1980, s. 14) beskriver, at læremidler først og fremmest tilbyder læreren støtte til strukturering, repræsentation, styring, motivation, differentiering samt øvelse og kontrol. Det er lærerens opgave og ansvar at udvælge og tilrettelægge undervisningen, men læremidler kan støtte læreren heri. Derfor er lærerens brug af læremidler interessant.

Diverse kortlægninger af omfanget af brug af didaktiske læremidler i undervisningen peger på, at didaktiske læremidler i stort omfang bruges af lærere som grundlag for deres undervisning. Trends in International Mathematics and Science Study (TIMSS) 2011 viste, at $75 \%$ af grundskolelærere i matematik i 4. klasse og 77\% af lærerne i 8. klasse primært baserer deres undervisning på en matematikgrundbog (Mullis, Martin, Foy, Arora, 2012). I Danmark viser en undersøgelse, at over halvdelen af lærerne i dansk siger, at de bruger didaktiske læremidler i over halvdelen af undervisningstiden (Bundsgaard, Buch \& Fougt, 2017). Dette billede bekræftes i nationale kortlægninger på tværs af fag (Gilje, 2016; Atjonen, Halinen, Hämäläinen, Korkeako-ski, Knubb-Manninen \& Kupari, 2008), trods stor variation i læremiddelbaseringen på tværs af fag (Sigurgeirsson, 1992). Gilje et al. (2016) fandt, at læremidlernes indhold og didaktiske tilgang i høj grad determinerede den undervisning, der foregik i norske klasserum.

Læremidler spiller altså en væsentlig rolle for undervisningen, og i denne undersøgelse er vi særligt interesserede i at undersøge lærerens brug, transformation og (re)didaktisering af forskellige typer læremidler.

\section{Forskning om læremiddelbrug i danskundervisningen}

Danskfaget i grundskolen er med sit timetal og sin placering gen- 
nem hele skoleforløbet grundskolens største fag. Den undervisning, der foregår i dansk, er genstand for en stor del af den didaktiske forskning, der udføres i Danmark (eksempelvis Hansen, Elf, Misfeldt, Gissel \& Lindhardt, 2020; Kabel, 2020; Rørbech, 2016). En lille del af den didaktiske forskning angår undersøgelser af, hvilke didaktiske læremidler lærerne bruger i L1-undervisningen, og hvordan de bruger dem (Bundsgaard, Buch \& Fougt, 2017; Gissel \& Buch, 2020), men læremidler og læreres læremiddelbrug i L1 er et relativt uudforsket felt, både nationalt og internationalt (Gissel \& Buch, 2020). I en sammenligning af forskning i lærebøger udført i Australien og Finland mellem 2000-2011 fandt Wikman \& Horsley (2012), at der på området "research analysing activities in classrooms also including the use of educational aids" (Wikman \& Horsley, 2012, s. 45) var så få fund, at forfatterne valgte at udelade det i deres review. Et internationalt review af læremiddelforskningen i Norden og fem andre europæiske lande i perioden 2000-2011 (Knudsen, 2011) viste, at forskningen $\mathrm{i}$ læremidler fortrinsvis var fokuseret på læremidlernes indhold og sekundært læremidlernes form, og at der sjældent i forskningen skete en triangulering af indholds-, form- og brugsanalyser. Metodisk var observationer i klasserum og interviews med brugere af læremidler en sjældenhed.

I 1994 undersøgte Borstrøm, Petersen \& Elbro (1999) brugen af læseundervisningsmaterialer i indskolingen og læremidlernes sammenhæng med elevernes læseudvikling og læselyst og fandt, at elevers læseudvikling bedst understøttes, hvis læremidlerne indeholder meget tekst og er funderet i bogstav-lydprincippet. Et større studie fra 2014 undersøgte alle fags læremiddelbrug med fokus på didaktiske læremidler og deres didaktiske tilgang (Pettersson, Hansen, Kølsen \& Bundsgaard, 2016). Gissel og Skovmands (2018) analyse af disse data viste, at de anvendte læremidler for de flestes vedkommende var domineret af en trænende didaktisk tilgang. Samme år gennemførte Undervisningsministeriet en undersøgelse af brugen af digitale læremidler i alle fag, der også fokuserede på læremidlernes didaktiske tilgang (se mere i for eksempel Hansen \& Bundsgaard, 2013; Rambøll Management \& The Boston Consulting Group, 2014). Konklusionen var, at der blev anvendt repetitive, formidlende og stilladserende didaktiske, digitale læremidler i "næsten lige stort omfang" (Rambøll Management \& The Boston Consulting Group, 2014, s. 7), et resultat, der senere blev kritiseret af Gissel \& Skovmand (2018), som fandt, at trænende træk var dominerende i de digitale læremidler, som lærerne anvendte, men også, at de fleste læremidler havde kombinationer af flere træk og dermed ikke entydigt faldt i en enkelt kategori. 
I 2017 udkom Loeremidlernes danskfag (Bremholm, Bundsgaard, Fougt \& Skyggebjerg), der ved brug af et mixed method-studie med en deskriptiv tilgang undersøgte, hvilke læremidler lærerne bruger og foretrækker. Studiet viste, at få læremidler dominerer i danskundervisningen. Derudover gennemførtes kvalitative tekstbaserede analyser af de mest anvendte læremidler ud fra forskellige perspektiver. Studiet indeholdt ikke undersøgelser af, hvordan lærere brugte læremidlerne eller med hvilket udkomme.

Læreres brug af læremidler i danskundervisningen/L1-faget i et internationalt perspektiv blev undersøgt i et review i 2020 (Gissel \& Buch, 2020). Studiet viser først og fremmest, at antallet af studier i brug af læremidler i skolen er meget begrænset, idet man kun fandt 18 studier i perioden 2008 til 2018. I reviewet blev de inkluderede studier analyseret ud fra perspektiver på enten læreren, eleverne eller læremidlerne selv samt på kombinationer heraf. Fokus på interaktionen mellem læremidlerne og læreren eller eleverne udgør den største gruppe af studier (syv i alt), men i disse flyttes fokus ofte fra læremidlerne til mere generelle pædagogiske diskussioner og teoriudviklinger, hvorved fokus også flyttes væk fra, hvordan lærere faktisk bruger læremidlerne (Gissel \& Buch, 2020). Reviewet fandt desuden få studier, der fokuserer på elevernes udkomme af brugen af et bestemt læremiddel, og kun to studier har undersøgt elevernes udbytte af læremidlet korreleret med brugen heraf (Fälth, 2013; Gissel \& Buch, 2020). I det samlede review-studie konkluderes, at der mangler forskning i læremidlers brug i undervisningen med fokus på observation af læremiddelbrug, interview af lærere og elever, undersøgelser af læremidlers effekt samt undersøgelser af læremidlernes potentielle læringspotentiale.

\section{Datagrundlag og analysestrategi}

I projektet "Praksisfortolkninger af læremidler" (PaL), som er finansieret af Nationalt Videncenter for Læremidler i Danmark, er målet at forstå, hvordan lærere bruger læremidler og det samspil der sker mellem det didaktiske læremiddels intenderede design og lærerens undervisning. I et delprojekt, som fokuserer på modersmålsundervisning, har vi som data brugt videoobservationer fra projektet Linking Instruction and Student Achievement in Nordic Schools (LISA Nordic). En præmis ved vores datagenbrug er således, at vi ikke selv har selekteret cases. LISA Nordic er et storskalaprojekt, der har indsamlet videooptagelser fra mere end 150 forskellige klasserum i Norden. Ved hver observation pegede et kamera op mod forgrunden af klasserummet, hvor læreren og tavlen typisk befinder 
sig, mens det andet filmede den anden vej, på eleverne. Der var tale om åbne, ikke-deltagende observationer, hvor læreren var udstyret med en trådløs mikrofon, så optagelserne tydeligt indfanger lærerens udsagn. Elevernes ytringer blev optaget med kameraernes indbyggede mikrofoner og er derfor ikke altid tydelige. Således egner data sig til at fokusere på lærerens handlinger med læremidler, hvilket vi gør i denne undersøgelse.

LISA Nordic havde som intention at indsamle observationer fra fire på hinanden følgende lektioner i hver klasse i et eller flere af de tre fag dansk, matematik og samfundsfag, som indgik i projektet. I danskprojektet gav dette 25 observerede lektioners danskundervisning på 7. klassetrin fordelt på otte skoler. I Appendix A findes en oversigt over vores cases med angivelse af lærernes skoletilhørsforhold, og hvilken af de observerede lektioner med lærer-en der er tale om, samt hvilke didaktiske, semantiske og funktionelle læremidler vi har iagttaget $\mathrm{i}$ brug i hver case.

Videoobservationen kan karakteriseres som "video som linse" (Hansen \& Carlsen, 2017, s. 56), idet videokameraet bruges som et blik ind på undervisningen med henblik på at beskrive de kvalitative træk, der fokuseres på i undersøgelsen: Hvilke læremidler bringes i anvendelse i lærerens undervisning, og hvordan bringes de i anvendelse? At vi ikke selv har skabt videodata betyder, at vi ikke har fået en fornemmelse for de aspekter af situationen, som video ikke kan indfange, for eksempel stemninger eller andre typer af informationer, man opfanger, når man selv observerer, eksempelvis materialer på elevernes bord. Til gengæld er en af videomediets affordances (muligheder), at det fastholder alle handlinger i optagefeltet - også dem, der ikke umiddelbart påkalder sig opmærksomhed, og som forskeren måske ikke i første omgang hæfter sig ved og noterer i sine feltnoter, men som ved senere analyser kan vise sig at fange for eksempel rutinerede eller ritualiserede handlinger (Jank \& Meyer, 1997), hvilket er særligt relevant, når det gælder undersøgelse af lærernes brug af læremidler.

Ellen Krogh har udviklet en model til at analysere danskfaget med, som består af tre indbyrdes relaterede elementer: teoretisk praksis, kulturel praksis og diskursiv praksis, som hun fremstiller i en triadisk model (Krogh, 2003; Krogh, 2011). Observation giver mulighed for at undersøge den kulturelle praksis. Den kulturelle praksis bestemmer Krogh som den måde, fagundervisning etablerer og udvikler sig på i et praksisfællesskab (Krogh, 2011, s. 44), og hun peger på, at "[d]et analytiske begreb som produktivt kan bringes i anvendelse i forhold til den kulturelle praksis, er et bredt semiotisk genrebegreb, som det er udviklet af Sigmund Ongstad (1997)" (Krogh, 2011, s. 44). Med dette genrebegreb fokuseres ikke kun på verbalsproget (hvad 
lærere og elever siger), men på hele den multimodal kommunikation i klasseværelset med særlig vægt på at identificere og undersøge de kommunikative mønstre, der gør faget genkendeligt for dets deltagere. De inkluderede videoobservationer giver os mulighed for at undersøge et aspekt af lærernes kulturelle praksis, nemlig deres læremiddelbrug, som den gøres i aktualiseret danskundervisning.

I vores dataanalyse fokuserer vi på, hvilke didaktiske, semantiske og funktionelle læremidler der bringes i anvendelse i de observerede lektioner. Vi interesserer os for, hvordan brugen af læremidlerne rammesættes af læreren samt forholdet mellem det intenderede design i læremidlerne (som det fremtræder i lærervejledning og elevdel) i de didaktiske læremidler og den aktualiserede undervisning.

Således er der tale om en eksplorativ og deskriptiv undersøgelse, da vi har adgang til 25 øjebliksbilleder af danskundervisning i udskolingen, hvor vi alene ud fra videodata har opbygget en forståelse af, hvad der er foregået i lektionerne, dvs. hvad læreren og eleverne gør og med brug af hvilke læremidler. Dog opsøgte vi de deltagende lærere med henblik på at filme en ekstra lektion og gennemføre et interview med dem. Målet med denne ekstra empiriindsamling var dels, at vi gennem observationen selv ville opleve læreren, klassen og skolen, og dels, at vi gennem kvalitative enkeltinterviews med lærerne $\emptyset n s k e d e$ indblik i og forståelse for lærerens brug af læremidlerne set fra lærerens perspektiv. Gennem observationerne kan vi se, hvad lærerne $g \emptyset r$ med læremidlerne, men vi kan ikke se, hvorfor læreren netop bruger disse læremidler, ligesom vi ikke kender lærerens overvejelser over deres brug. Hvis læreren eksempelvis følger det didaktiske læremiddels intentioner, således som disse kommer til udtryk i lærervejledning og andre paratekster, kan det både være udtryk for et bevidst valg (læreren har analyseret og vurderet, at netop dette læremiddel på netop denne måde indfrier lærerens didaktiske mål), men det kan også være udtryk for, at læreren ikke har haft mulighed for at undersøge læremidlet nærmere og derfor ibrugtager det uden didaktiske til- og fravalg. Kun to lærere ud af otte indvilligede i dette, så vi har udeladt disse data fra analyserne. Uden at have adgang til lærernes beskrivelser af og refleksioner over deres undervisning kan vi heller ikke vide, om læreren eksempelvis har ladet sig inspirere til en aktivitet af et læremiddel uden at inddrage læremidlet eksplicit i undervisningen. Vi kan kun analysere samspillet mellem læremiddel og aktualiseret undervisning i de tilfælde, hvor vi kan se og/eller høre, at der bruges et konkret læremiddel.

Observationerne er delvist transskriberet og kodet ud fra en række læremiddel-, fag- og almendidaktiske kategorier. Vores analyser og fremstilling af fund er opdelt i en beskrivelse af, hvilke læremidler der faktisk tages i brug i danskundervisningen, en karak- 
teristik af læremidlerne og dernæst en analyse af, hvordan de bruges, dvs. hvordan læreren rammesætter brugen af læremidlerne i undervisningen, samt de tegn på valg i forhold til anvendelsen af læremidlerne, som vi kan registrere i observationerne.

\section{Brugen af didaktiske læremidler}

Ovenfor definerede vi didaktiske læremidler som læremidler, der er produceret specifikt med henblik på undervisning. Vi berørte desuden, at et didaktisk læremiddel vil befinde sig et sted på et kontinuum fra høj til lav didaktiseringsgrad (J. J. Hansen, 2010), afhængigt af hvor bred en vifte af de didaktiske grundfunktioner læremidlet understøtter eller varetager. Didaktiske læremidler med en høj didaktiseringsgrad indeholder således både mål, indhold, metoder og aktiviteter, og udpeger en sammenhæng mellem disse, hvorimod didaktiske læremidler med lav didaktiseringsgrad for eksempel kun udpeger indhold og aktiviteter (J. J. Hansen \& Gissel, 2019). Vi vil forvente, at læremidlets didaktiseringsgrad har indflydelse på, hvordan læreren tager det i anvendelse. Det vil være ønskeligt, at læreren i forhold til et læremiddel med lav didaktiseringsgrad som minimum træffer didaktiske valg på de centrale didaktiske områder, som læremidlet ikke varetager. Pointen med begrebet redidaktisering (J. J. Hansen, 2006) er bl.a., at det didaktiske læremiddel fra producentens side er didaktiseret, hvorved lærerens didaktiske supplement bliver en redidaktisering af det allerede didaktiserede. Men i forhold til de aspekter af undervisningen, som det lavt didaktiserede læremiddel ikke forsøger at tage vare på, må vi tale om didaktisering fra lærerens side, når læreren aktivt træffer didaktiske valg. I forhold til højt didaktiserede læremidler er det mere åbenlyst at tale om redidaktisering af læremidlet som helhed.

I vores case-analyser vil vi fremanalysere de didaktiske læremidlers didaktiseringsgrad ud fra dokumentanalyser af læremidlerne. Dette vil vi holde op mod lærerens brug af læremidlet; nærmere bestemt interesserer vi os for, om læreren rent faktisk redidaktiserer og didaktiserer de lavt didaktiserede læremidler, samt om læreren redidaktiserer de højt didaktiserede læremidler, eller om der er tale om ibrugtagning. Dette giver to krydsende spændingsfelter, som illustreret i firefeltsmodellen (Figur 1). 
Figur 1.

De krydsende spændingsfelter mellem

henholdsvis høj og lav didaktiseringsgrad

samt ibrugtagning kontra redidaktisering af

didaktiske læremidler.

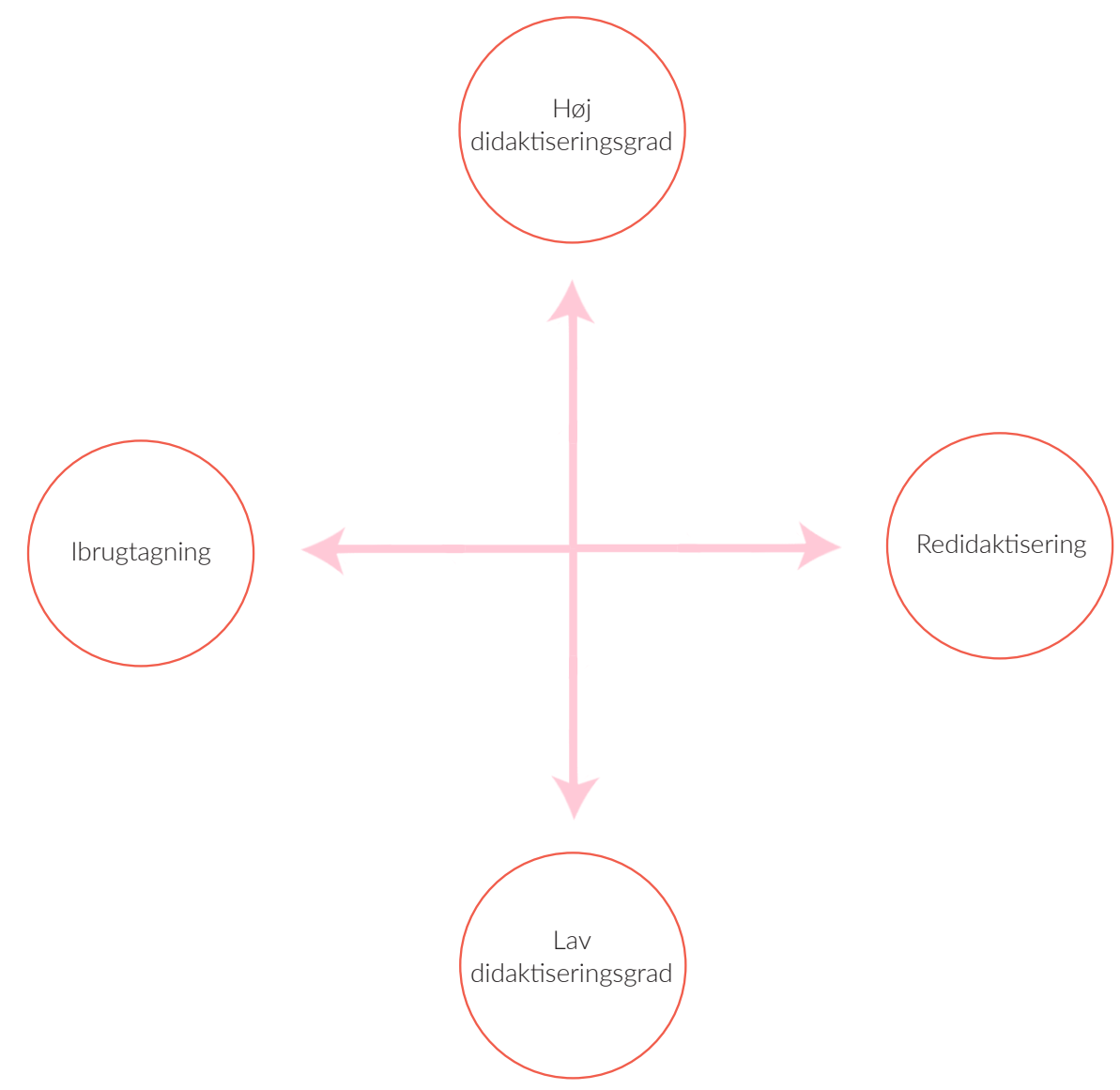

I vores casebeskrivelser har vi valgt at præsentere dem i rækkefølge efter didaktiseringsgraden af de didaktiske læremidler, vi har observeret brugt i undervisningen. Vi ser nemlig anvendelse af didaktiske læremidler, der spænder lige fra det højt didaktiserede forløb i et forlagsproduceret system eller en fagportal til anvendelse af minimalt didaktiserede enkeltstående ressourcer, som oftest har andre afsendere end de større forlag (Gyldendal, Alinea og Clio Online). Denne progression i casebeskrivelserne fra høj til lav 
didaktiseringsgrad i de anvendte læremidler tjener til, at læseren kan følge de eventuelle forskydninger i lærernes brug af læremidler med forskellige didaktiseringsgrader. Vi har forsynet hver forekomst af et didaktisk læremiddel med et nummer (for eksempel DL1) med henblik på at kunne udpege dem i teksten (se Appendiks A).

\section{Casebeskrivelser}

\section{Forløb fra systemer og fagportaler}

Lærer 2 på skole 5 anvender systemet Fandango til 7. klasse (DL19a), et læremiddel til litteraturundervisning, i begge de observerede lektioner. Fandango er et højt didaktiseret læremiddel med en elevog lærerdel. Der er lærervejledning til hver del af kapitlerne, som redegør for fagligt fokus, mål, indeholder skitser til en lærerfaglig analyse af primærteksterne, en gennemgang af og begrundelse for aktiviteterne, tips til punkter, der kan bringes i spil, og bud på relevante svar. Lærervejledningen gennemgår i den generelle del grundigt, hvad der skal forstås ved at analysere, læse mellem linjerne, og de strategier, som eleverne skal anvende, forklares omhyggeligt. Lærerens anvendelse kan betegnes som ibrugtagning snarere end redidaktisering. I den første observerede lektion med denne lærer (case 18) skal eleverne arbejde med et arbejdsark fra "Fandango", og i den følgende lektion skal eleverne arbejde med billedanalyse ud fra en skriveguide fra Fandango (case 18). Læreren har i begge lektioner svært ved at forklare, hvad aktiviteterne går ud på. I en af lektionerne læser læreren op fra opgaveformuleringen og lægger ikke så meget til i sin rammesætning. I den anden observerede lektion ender læreren med at henvise eleverne til at læse opgaveformuleringen i læremidlet.

På skole 8 arbejder klassen i tredje og fjerde observerede lektion (hhv. case 25 og 26) også med Fandango til 7. klasse (May \& Arne-Hansen, 2013, DL19b). De er i gang med et forløb om intertekstualitet. Læreren introducerer i case 25 forløbet, men lægger ikke det store til (ibrugtagning). Dog indleder læreren lektionen med en klasserumsdialog om, hvad eleverne ved om intertekstualitet, varianter af intertekstualitet mv. Når eleverne er færdige eller trænger til en pause, kan de arbejde med Grammatip (DL16b). Grammatip er et digitalt, didaktisk læremiddel med selvrettende (lukkede) træningsopgaver til grammatik. Brugen af Grammatip rammesættes ikke af læreren. Læreren peger blot opgaver ud, som eleverne kan gå i gang med, og der er igen tale om ibrugtagning. I den næste lektion skal arbejdet med intertekstualitet fortsætte med udgangspunkt i tre uddrag fra Bent Hallers novelle "Skyld" (2011). Læreren viser blot eleverne ind i læremidlet (DL19b) og beder dem om at arbejde løs: "I 
skal følge det, der står”. I rammesætningen beder læreren eleverne om at arbejde med strategierne "opsummer" og "forudsig" i par, på trods af at læremidlet i forløbet også arbejder med strategierne "at stille spørgsmål” og "at opklare”. Desuden organiserer læreren arbejdet som pararbejde, selv om læremidlet foreslår grupper på fire. Læreren følger således ikke læremidlets intenderede design på alle punkter. Vi ser dette som et nødvendigt valg fra lærerens side, idet der kun er to strategier i spil i det aktuelle forløb, og da ikke alle fire strategier er i spil, giver det også god mening kun at være to om aktiviteterne. Således redidaktiserer læreren ved at fokusere elevernes opmærksomhed på de aktuelt relevante strategier og ved at vælge en alternativ organiseringsform i forhold til den, læremidlet foreslår. Men lærerens rammesætning af den faglige aktivitet må karakteriseres som ibrugtagning.

I en dobbeltlektion på skole 2 (case 4 og 5) ser vi en kontrapunktisk brug af et højt didaktiseret didaktisk læremiddel, dvs. hvor lærerens didaktiske design går stik imod læremidlets intenderede design. Læreren tager afsæt i et forløb i det analoge system "Tid til dansk. Luk vinduet op" (Olsen-Bülow, Skaarup \& Harms, 2002, DL7), som er et højt didaktiseret system med lærervejledning, målangivelser, elevopgaver og evalueringstiltag. Læreren fravælger at bruge læremidlets didaktisering i undervisningen med novellen "Alene hjemme" (Beckmann, 2002) og bruger i stedet novellen som semantisk læremiddel. Læreren lægger nemlig op til, at eleverne selv skal 'didaktisere' novellen med fokus på nogle temaer (eksempelvis miljø, berettermodellen, in medias res). Eleverne skal helst ikke kigge i grundbogen, men selv lave spørgsmålene til teksten. Dermed kan læreren ikke finde støtte i læremidlet til sit didaktiske design. Lærerens rammesætning er forholdsvis tydelig omkring, hvad eleverne skal gøre.

Læreren på skole 2, som gik kontra i forhold til det intenderede design i "Luk vinduet op", blev observeret i yderligere to lektioner (case 6 og 7). Denne gang anvendte hun det digitale læremiddel Gyldendals fagportal, nærmere bestemt forløbet "Hos regnormene" (Gyldendal, u.å., DL8), som handler om skriftlig fremstilling. Igen er der tale om et højt didaktiseret læremiddel, idet der er en lærervejledning, der gennemgår hvert forløbs stilladserende delopgaver, som støtter eleverne i at nå i mål med at opfylde skriveordrens krav. Ud over målangivelser og elevaktiviteter er der omfattende evalueringstiltag. I disse lektioner følger læreren læremidlets intenderede design tæt. Læreren læser bl.a. op af opgaveformuleringerne i sin rammesætning. Men opgaven er eksamensforberedende, og læreren supplerer med spørgsmål om, hvilke krav opgaven stiller til dem - sandsynligvis for at eleverne skal lære at aflæse en skriveordre i det kommende 
eksamenssæt. Læreren gennemgår desuden grundigt hver delopgave. Læreren supplerer læremidlets design med en elev-elevsparringsrunde, hvilket virker som et godt afbræk fra det individuelle arbejde, som læremidlet lægger op til. Det er interessant at iagttage, at samme lærer vælger hhv. at forkaste et foreslået didaktisk design i et didaktisk læremiddel (ekstrem redidaktisering) og følge et didaktisk læremiddels foreslåede design tæt (ibrugtagning med elementer af redidaktisering).

Læreren på skole 8 arbejder ligeledes i den anden observerede lektion (case 24) med et forløb fra Gyldendals fagportal til dansk (DL24). Læreren forklarer, hvad eleverne skal beskæftige sig med: hvordan man konstruerer sætninger, og hvorfor det er vigtigt at vide noget om. Eleverne får, på trods af at læremidlet har bud på organisering, at vide, at de selv må vælge mellem individuelt arbejde eller gruppearbejde. Her ser vi en grundig rammesætning i forhold til et højt didaktiseret læremiddel, men ikke redidaktisering fra lærerens side.

På skole 8 skal eleverne i første observerede lektion arbejde med sms-novellen "Efter festen" af Renée T. Simonsen (u.å.). Gruppearbejdet og den efterfølgende litteratursamtale på klassen tager udgangspunkt i de fire sidste spørgsmål fra et forløb på danskfaget.dk (Pedersen \& Tingleff, u.å., DL23) om denne novelle. Danskfaget.dk er et forlagsproduceret, didaktisk læremiddel og er kendetegnet ved at være et højt didaktiseret læremiddel med målangivelser, arbejdsspørgsmål mv. Lærervejledningen beskriver det særlige ved genren og nogle fokuspunkter, målangivelse mv. Læreren henviser her til opgaven i læremidlet og til de rutiner, klassen har for efterfølgende klasserumsdialog. Der er således tale om ibrugtagning.

\section{Højt didaktiserede enkeltstående ressourcer}

Der er flere eksempler på anvendelse af udprintede ark eller PDF-filer, som ikke relaterer sig til et undervisningssystem. Vi betegner disse som enkeltstående ressourcer.

På skole 4 blev to klasser observeret i tre lektioner hver. I begge klasser arbejdede lærer og elever med et forløb om den grafiske roman "Kopierne" af Jesper Wung-Sung (2010). Den ene lærer anvendte ikke eksplicit et didaktisk læremiddel til arbejdet; denne case behandles under afsnittet Semantiske læremidler (case 10). Den anden lærer anvendte et undervisningsforløb udviklet af CFU, et såkaldt pædagogisk overlay (Joost, 2017, DL12). Læremidlet er højt didaktiseret, idet der i læremidlet henvises til Fælles Mål, formuleres læringsmål, og der beskrives et samlet forløb med aktiviteter og forslag til organisering og metodik, eksempelvis "CL- 
struktur: Tænk-par-del”. Men læremidlet kræver redidaktisering, da det kun består af en lærervejledning og analyseark. Således er kun analysearkene elevhenvendte; resten af læremidlet henvender sig eksklusivt til læreren. Læreren følger læremidlets intenderede didaktiske design tæt. Læreren læser direkte op fra læremidlet i sin rammesætning og lægger selv lidt forklaring til, da forklaringen som nævnt ikke er elevhenvendt. Nogle steder i lærervejledningen er der indskrevet valgmuligheder for læreren, for eksempel skal læreren eller eleverne tage stilling til, hvordan resultatet af analysen formidles. I den observerede lektion træffer læreren valget for eleverne: Der skal bruges Prezi. At læremidlet næsten udelukkende henvender sig til læreren nødvendiggør således, at læreren i et eller andet omfang medierer mellem læremiddel og elever. I den observerede undervisning er redidaktiseringen dog minimal fra lærerens side.

Også læreren på skole 7 anvender et pædagogisk overlay fra CFU til undervisning i romanen "Kviksand" af Daniel Zimakoff (Westergaard, 2018, DL22). Læreren følger ikke læremidlets didaktiske design, men plukker i stedet en enkelt aktivitet fra læremidlet. I den første del af den observerede lektion skal eleverne arbejde med personkarakteristik. Denne aktivitet indgår ikke i CFU-læremidlet, og vi har ikke været i stand til at koble aktiviteten til et specifikt læremiddel. Der er altså tale om lærerens redidaktisering af læremidlet. Men i næste sekvens af lektionen skal eleverne arbejde med at finde vendepunkter i romanen og skrive, hvilken betydning vendepunkterne har for den videre handling med afsæt i CFU-læremidlet. Læreren rammesætter aktiviteten med at finde vendepunkter ved at veksle mellem at læse højt af opgaveformuleringen og spørge, om eleverne ved, hvad et vendepunkt er. Lærerens brug af aktiviteten kan dermed karakteriseres som ibrugtagning, ikke redidaktisering, men læreren redidaktiserer i høj grad samlet set, da hun selv sammensætter et forløb af aktiviteter.

\section{Minimalt didaktiserede enkeltstående ressourcer}

En del af de observerede enkeltstående ressourcer har meget lav didaktiseringsgrad. Disse er opgaveark (eksempelvis udfyldningsark med grammatikøvelser, fagligt formidlende ressourcer (eksempelvis en gennemgang af appelformer) og processtrukturerende ressourcer (eksempelvis en analysemodel til reklamer).

På skole 6 arbejdes i første observerede lektion med besvarelser af opgaver i et kompendium (som distribueres i kopi) til Bjarne Reuters roman 7.a. (Vognstoft.dk, u.å., DL20). Læremidlet er lavt didaktiseret og består primært af en række spørgsmål til hvert kapitel uden begrundelser eller målangivelser. Derudover findes 
en lærerdel. Heller ikke i lærerdelen præsenteres begrundelser eller en fagdidaktisk forankring af de oftest lukkede opgaver i kompendiet, idet lærerdelen udelukkende indeholder løsninger på opgaverne. Arbejdet med at besvare de lukkede spørgsmål i læremidlet rammesættes ikke, eleverne skal blot gå i gang. I lektion 2 arbejdes videre med romanen. Læreren gennemfører en litteratursamtale ved at stille de spørgsmål, der står i det kopierede kompendium. Dette må betegnes som ibrugtagning.

Lærer 1 på skole 5 anvender i den observerede dobbeltlektion en enkeltstående netressource om reklamer og reklameanalyse (Hansen \& Jessen, u.å., DL17). Det er et lavt didaktiseret læremiddel, idet der i en elevhenvendt oversigt præsenteres analytiske begreber med forklaringer herpå; læremidlet er formidlende og processtrukturerende. Lærerens rammesætning af brugen af analysemodellen er uklar og minimalistisk. Læreren har fundet reklamer (semantisk læremiddel) som eksempler, og eleverne skal selv finde reklamer i ugeblade (semantiske læremidler), som de vil analysere. En tosproget elev, som ikke formår at deltage i undervisningen, får opgaver i Grammatip (DL16a). Her ser vi, at et læremiddel anvendes til elevdifferentiering; da Grammatip kun indeholder trænende aktiviteter (ikke formidlende eller stilladserende) og lukkede, selvrettende opgaver, er læremidlet velegnet til, at eleven kan anvende det uden lærerbistand.

De to lærere fra skole 1 bruger minimalt didaktiserede arbejdsark fra "MB-dansk" (Hundebøl \& Birgitte Therkildsen, u.å., DL 1, 2, 5 og 6) i de tre lektioner, som blev observeret. Der er tale om lavt didaktiserede læremidler, idet der i ressourcerne blot er beskrevet en aktivitet og en minimal facilitering af aktiviteten. Et eksempel er aktiviteten 'Øvelse 8: "Skriv en keeeedelig tekst"' (Hundebøl \& Therkildsen, u.å.-b). Læremidlet består af en side med overskriften, "Skriv en keeeedelig tekst", et billede af en hund, der ser ud til at kede sig og linjer til at skrive på. Materialet indeholder ikke en lærervejledning, målangivelser, begrundelser for aktiviteterne (ud over en generel introduktion i kompendiet, hvor pointen er, at man bliver bedre til at skrive, hvis man træner det). Ej heller opstilles faglige kriterier for de tekster, eleverne skal fremstille, bud på organisering eller evalueringstiltag. Øvelserne er dekontekstualiserede, og der knyttes ikke an til andre danskfaglige områder eller begreber. Disse didaktiske grundfunktioner og fagdidaktiske fokuseringer bliver dermed op til læreren. Læreren igangsætter imidlertid øvelserne med en minimal didaktisering. Læreren i case 1 uddyber formålet med arbejdet ved, at eleverne får at vide, at det er lige meget, hvad de skriver, de skal bare skrive løs. Man kan argumentere for, at lærerens ibrugtagning er i fuld 
overensstemmelse med læremidlets præmis, nemlig at træne skrivning som dekontekstualiseret aktivitet ud fra en betragtning om, at man bliver bedre til at skrive, hvis man skriver.

Også den anden lærer på skole 1 (case 3) anvender en af $\emptyset$ velserne fra dette lavt didaktiserede læremiddel (DL6). Heller ikke her opstilles faglige mål, men denne lærer redidaktiserer læremidlet ved at supplere med understøttende spørgsmål til læremidlets skriveordrer, som eksempelvis "Gad vide, hvad morgendagen bringer?”. Der er tale om en meget beskeden redidaktisering og primært ibrugtagning.

På skole 3 arbejdes der med talen som genre i alle de tre lektioner, vi har set. I de første to lektioner tages der udgangspunkt i dels en læreropstillet oversigt over tre elementer i talen: indholdet, appelformer og gestik/mimik (DL9), dels et udleveret kopieret ark om appelformer (DL10). Både dette ark og det lærerproducerede læremiddel på tavlen er eksempler på enkeltstående ressourcer med faglig formidling, der også kan fungere processtrukturerende for eleverne. De skal undersøge semantiske læremidler med brug af viden fra arket og oversigten, og eleverne skal bruge de tre elementer og appelformerne som struktur for deres analytiske og produktive arbejde.

Det omdelte ark med den faglige formidling bruger læreren en del tid på at didaktisere gennem faglige uddybninger, eksempler og ved at opstille mål for elevernes brug af arket, ligesom arbejdsformer forklares og uddybes. Læreren italesætter brugen af appelformer som svært stof, og hans didaktisering består blandt andet også i at relatere stoffet til det arbejde, eleverne selv skal i gang med, nemlig en tale til deres konfirmation, ved at forklare, hvordan appelformer kan bruges som virkemidler i deres egen tale og hvordan. Han får på den måde relateret et stof, han selv italesætter som vanskeligt, til elevernes konkrete opgave og erfaringsverden, og får uddybet det faglige stof. Også i den efterfølgende lektion ser vi den samme tydelige didaktisering fra lærerens side.

Denne undervisning er et eksempel på en lærer, der i høj grad anvender lavt didaktiserede læremidler som baggrund for den faglige læring, og som gennem sin grundige didaktisering af både fagligt stof, aktiviteter, faglige mål og arbejdsformer gør det tydeligt for eleverne, hvad de skal vide, og hvad de skal bruge deres viden til, og dernæst lader eleverne bruge deres faglige viden til analyser af relevante, semantiske læremidler. Alt i alt ser vi her et eksempel på en lærer, der tager opgaven med at didaktisere lavt- eller ikke-didaktiserede læremidler på sig. Også i case 15, 16 og 21 ser vi en minimal didaktisering af minimalt didaktiserede enkeltstående ressourcer fra lærerne. Samlet set viser vores empiri, at brugen af enkeltstående 
ressourcer med meget lav didaktiseringsgrad ikke didaktiseres i tilstrækkeligt omfang fra lærernes side. Ud af de forskellige anvendelser af enkeltstående ressourcer med lav didaktiseringsgrad ser vi altså ikke megen didaktisering fra lærernes side. Der sker en vis rammesætning, der primært går på arbejdsstrukturen i nogle af vores cases, og som kan siges at være en didaktisering af aktiviteter, men især udelades en forklaring på de faglige mål og begrundelser for, hvorfor der skal arbejdes med det faglige stof. Vi ser kun én lærer, der grundigt didaktiserer læremidlet i forhold til aktiviteter og mål, for eksempel ved at opstille selvproducerede mål for undervisningen, og som didaktiserer i forhold til indhold ved at give eleverne uddybende, faglige forklaringer og begrundelser. Dertil ser vi et eksempel på en lærer, der i et eller andet omfang opstiller en form for mål for eleverne, fordi eleverne rent faktisk spørger, hvorfor øvelsen skal laves.

\section{Fravær af didaktiske læremidler}

I fire af de observerede lektioner (case 10, 11, 12 og 15) var der ikke et didaktisk læremiddel i anvendelse. Det er i sig selv et interessant fund, at lærerne i omkring en sjettedel af lektionerne fravælger den støtte og facilitering, der ligger i at bruge et didaktisk læremiddel.

\section{Delkonklusion om brugen af didaktiske læremidler}

Generelt iagttager vi læreres ibrugtagning af de didaktiske læremidler, hvad enten læremidlerne er højt eller lavt didaktiserede (Figur 2). Ud over den afvigende case 7 med den kontrapunktiske brug af et højtdidaktiseret læremiddel, er det primært uddybende forklaringer af begreber eller en løsnen op i forhold til læremidlernes foreslåede didaktiske design, der udgør de få tilfælde af redidaktisering af de højt didaktiserede didaktiske læremidler. 


\section{Figur 2.}

De didaktiske loeremidler, som vi har observeret brugt, indplaceret $i$ firefeltsmodellen.
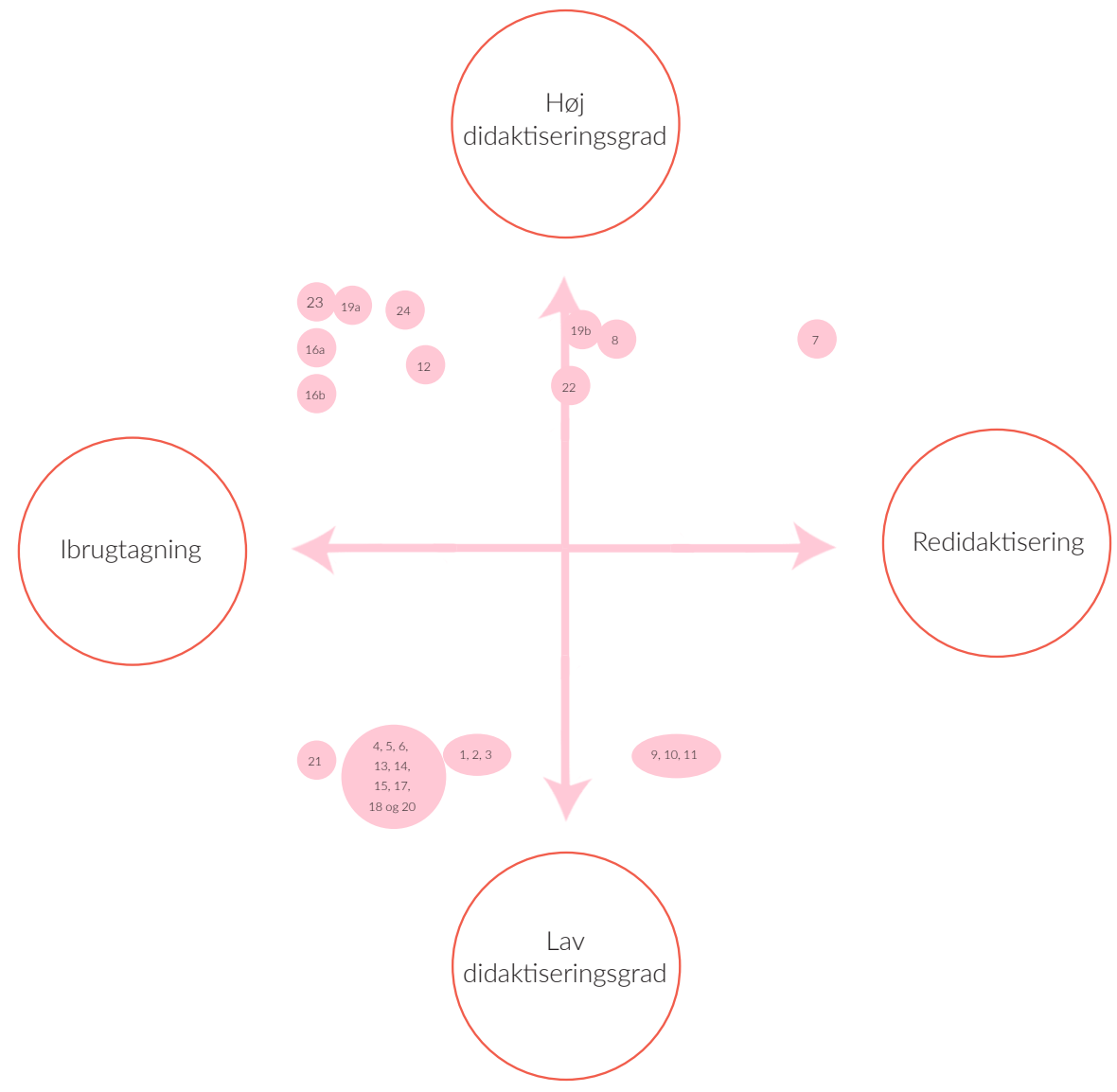

I forhold til de lavt didaktiserede enkeltstående ressourcer ser vi også primært en ibrugtagning, hvilket har overrasket os, idet disse læremidler typisk ikke giver bud på andre didaktiske kategorier end indhold. Undervisningen bliver jo afviklet, så der træffes valg om for eksempel organisering og opsamling/evaluering, men lærerne ekspliciterer kun det absolut nødvendige i deres rammesætning og etablerer sjældent en faglig kontekst for aktiviteterne. 


\section{Semantiske læremidler i danskundervisningen}

Som tidligere nævnt er semantiske læremidler tekster og ting, der ikke er produceret med undervisning for øje, og som har en betydning og funktion i samfundet uafhængigt af undervisningskontekster (Hansen \& Skovmand, 2011, s. 19). Semantiske læremidler er betydningsbærere og bruges til at bringe indhold ind i undervisningen, men uden at have en indbygget didaktik (Hansen \& Skovmand, 2011, s. 19). De semantiske læremidler er en kilde til viden, og samtidig kan de semantiske læremidler give eleverne en umiddelbar, konkret og sanselig oplevelse, som dog samtidig kræver refleksion, undersøgelse og udvikling af begreber, når fagligheden skal udvikles (Hansen \& Skovmand, 2011, s. 19).

Når læreren skal didaktisere semantiske læremidler, må det ske på baggrund af forskellige didaktiske overvejelser. Jens Jørgen Hansen skelner mellem tre kriterier, som det semantiske læremiddel skal leve op til (Hansen \& Skovmand, 2011, s. 54-55). For det første skal læremidlet kunne legitimeres. Læreren skal vurdere læremidlets faglige relevans, eksempelvis med udgangspunkt i egen faglighed og fagets læseplaner, så eleverne kan tilegne sig fagets viden og færdigheder. For det andet skal stoffet kunne repræsenteres, så det kan gøres til genstand for læring, og for det tredje skal læremidlet være lærbart, så det kan fungere som grundlag for elevernes læreprocesser. For eksempel må tema og sprog appellere til elevernes nysgerrighed og oplevelser, samtidigt med at det giver mulighed for et fagligt udbytte. I sidste ende er udbyttet af arbejdet med den semantiske tekst dog afhængig af lærerens didaktisering, og det er derfor interessant at undersøge, hvordan lærerne didaktiserer disse læremidler.

Grænserne mellem didaktiske, semantiske og funktionelle læremidler er imidlertid flydende. Semantiske læremidler er en del af mange didaktiske læremidler, og i observationerne ser vi eksempelvis, at en lærer vælger en novelle, der indgår i et didaktisk læremiddel, men hun anvender novellen som et semantisk læremiddel (case 4 . og 5). Andre gange anvender læreren eksempelvis en roman, som didaktiseres ud fra enkeltstående netressourcer (eksempelvis case 13), eller læreren didaktiserer selv læremidlet (eksempelvis case 12).

\section{Brugen af semantiske læremidler}

I analyserne af de semantiske læremidler skelner vi mellem praktiske tekster, fagtekster og æstetiske tekster, hvor æstetiske tekster er et overbegreb for skønlitterære tekster, som også omfatter film, billeder og spil (T. I. Hansen, 2015, s. 42). Danskfaget kan beskrives som et tekstfag (J. J. Hansen, 2012; T. I. Hansen, 2015; Krogh, Elf, Høegh, 
\& Rørbech, 2017), og semantiske læremidler i danskfaget udgøres i nærværende undersøgelse af tekster, primært æstetiske og praktiske tekster.

\section{Casebeskrivelser}

På skole 4, (case 15) skal eleverne på baggrund af en læsning af Louis Jensens "Rejsen til min far" skrive en anmeldelse af bogen. Opgaven stilladseres meget lidt, og læreren skifter mellem at kalde opgaven for en anmeldelse og et resumé. Forskellen defineres ikke, og eleverne får at vide, at de bare skal skrive løs i 40 minutter, og besvarelsen skal fylde en halv til en hel side. De elever, der ikke har fået læst bogen, må skrive om noget andet, for eksempel en anden bog, et spil eller en film, de har set. Timen rundes ikke af, og nogle elever er ikke færdige. De skal alligevel aflevere opgaven til læreren. I denne case bruger læreren det semantiske læremiddel som afsæt til en opgave, som er meget løs, både indholdsmæssigt og formmæssigt. Eleverne skal bare "skrive løs", og formmæssigt er der ingen krav.

På skole 4. (case 11 og 13) ses to forskellige måder, hvorpå lærerne vælger at bruge semantiske læremidler i form af æstetiske tekster. I begge cases arbejdes med Kopierne, en ungdomsroman af Jesper Wung-Sung (2010), men lærerne didaktiserer læremidlet meget forskelligt.

På skole 4, ser vi to lektioner (case 10 og 11), hvor klassen på baggrund af Kopierne arbejder med at forberede en paneldiskussion. Paneldiskussion skal foregå som et rollespil, og i lektionen arbejder eleverne med at forberede argumenter og holdninger i forhold til den rolle, de har fået tildelt. Diskussionen skal handle om, hvorvidt kloning er acceptabelt eller ej, samt de dilemmaer, det indebærer, og hver gruppe skal danne sig en holdning til emnet. Læreren stilladserer opgaven grundigt og skriver målet for dagens arbejde på tavlen: eleverne skal argumentere ud fra begreberne etos, patos og logos. Læreren arbejder i denne lektion ud af romanen og underviser med litteraturen. Romanen bruges på baggrund af dens temaer til at lære eleverne noget om retorik og argumentation. Som beskrevet ovenfor, arbejder de i parallelklassen på samme skole (case 13) også med Jesper Wung Sungs (2010) Kopierne, men her ud fra en analysemodel (et didaktisk læremiddel, DL12). Læreren gennemgår arket på klassen ved at læse højt herfra, og der er meget lidt stilladsering undervejs i lektionen.

Det samme ser vi på skole 6 , case 20 , hvor eleverne arbejder med det semantiske læremiddel 7.a. af Bjarne Reuter (1992), som i undervisningen kombineres med et ikke-forlagsproduceret enkeltstående, lavt didaktiseret læremiddel fra vognstoft.dk (u.å., 
DL20, se case-beskrivelse ovenfor).

Når lærerne arbejder med praktiske tekster, griber de det også forskelligt an. På skole 5, case 16 og 17, har vi observeret en dobbeltlektion, hvor eleverne arbejder med reklamer, både digitalt og analogt. Læreren har på nettet fundet eksempler på reklamer, og på klassen drøfter de kort, hvorfor de viste reklamer er gode eller mindre gode at analysere. Fokus er her på, hvilke reklamer der virker godt i en eksamenssituation og ikke så meget på selve analysen. Herefter skal eleverne selv finde velegnede reklamer i ugeblade, som de skal analysere i grupper på baggrund af et analyseskema til reklameanalyse (DL17, se case-beskrivelse ovenfor).

På skole 4, case 12, arbejdes også med praktiske tekster, og her har læreren planlagt et forløb om sociale medier ud fra begreberne 'reality' og 'selviscenesættelse'. Læreren skriver målene på tavlen: eleverne skal kende til og kunne forklare de to begreber 'reality' og 'selviscenesættelse'. Efter en klasserumssamtale om begreberne, viser læreren klip af forskellige youtubere (eksempelvis Lærke Holmberg og Alexander Husum) og tv-programmer. Evalueringen foregår ved, at eleverne skriver på post-it-sedler: "Selviscenesættelse er..." og "Reality er...".

Læreren fortæller klassen, at hun i sin forberedelse har planlagt, hvilke YouTube-kanaler hun vil vise, og også har en overordnet en idé om, hvad hun vil spørge om på baggrund af de to fokusbegreber 'selviscenesættelse' og 'reality'. Men det er tydeligt, at læreren også er åben over for elevernes input, og på den måde kan man sige, at det semantiske læremiddel didaktiseres hen ad vejen, efterhånden som samtalen skrider frem. Måske derfor forbliver samtalen også ret generel og temmelig overfladisk, selvom læreren fremhæver, at det er vigtigt at være kritisk over for youtuberne og deres selviscenesættelse. Lærerens forventninger til, hvad det vil sige at forholde sig kritisk ekspliciteres imidlertid ikke.

De semantiske læremidler lægger som udgangspunkt op til flere anvendelsesmuligheder og brugen af dem er dermed mere uforudsigelig end tilfældet ofte er med de didaktiske læremidler. Her er det læreren, der på baggrund af en vurdering af læremidlets potentialer selv didaktiserer læremidlet (jf. legitimering, repræsentation og lærbarhed). Alligevel anvendes de semantiske læremidler generelt ret forudsigeligt, da de meget ofte anvendes i sammenhæng med didaktiserede analyseskemaer, som læreren finder på nettet. Det gælder både, når det drejer sig om æstetiske og praktiske tekster. 


\section{Funktionelle læremidler i danskundervisningen}

Som nævnt oven for er funktionelle læremidler de redskaber og værktøjer - eller man kunne sige hjælpemidler (Hansen \& Skovmand, 2011, s. 20) - som lærere og elever bringer i anvendelse i undervisningen for at understøtte læring og undervisning. Det kan for eksempel være en mobiltelefon, en kridttavle eller post-it-sedler. De funktionelle læremidler kan have mange forskellige funktioner i undervisningen. For eksempel kan digitale informationsteknologier være med til at understøtte kognitive og kommunikative processer i undervisningen fra input og bearbejdning af informationer til videndeling (Hansen, 2015, s. 3). De kan for eksempel bruges til produktionsopgaver, til præsentationer eller til søgninger. Også læseskriveteknologi er funktionelle læremidler.

Man kan således skelne mellem forskellige typer funktionelle læremidler ud fra deres funktion. Dette er dog ikke altid en iboende kvalitet ved det enkelte redskab, men handler i høj grad om, hvordan de enkelte læremidler anvendes. Man kan underinddele de funktionelle læremidler på mange måder. I analyserne af den observerede undervisning har vi kodet datamaterialet ud fra hverdagsbegreber om computer/pc, mobiltelefon og interaktiv tavle. Men i virkeligheden adskiller disse redskaber sig fra analoge redskaber ved deres multifunktionalitet. Hvor redskaber og værktøjer tidligere var udviklet med henblik på at udføre en bestemt opgave (for eksempel et kamera, der kunne tage et billede), er computerteknologien karakteriseret ved sin programmerbarhed og derved ved at være en potentiel maskine (Nielsen, Nielsen \& Jensen, 2005, s. 431). En smartphone kan meget mere end at ringe; den er også kamera, notesbog og adgang til information. Der er derfor også brug for at skelne mellem analoge og digitale funktionelle læremidler.

Ligesom de semantiske læremidler bærer de funktionelle læremidler ikke på en særlig didaktik, og læreren må derfor selv kunne se et didaktisk potentiale $i$ at bruge værktøjet $i$ undervisningen og selv rammesætte brugen af det ved for eksempel at opstille mål for brugen (Gissel, 2020). Det er derfor interessant at undersøge, hvordan lærerne didaktiserer disse læremidler. Når vi undersøger brug af funktionelle læremidler, undersøger vi derfor, hvad læreren gør med læremidlet, samt hvordan læreren rammesætter brugen af læremidlet over for eleverne.

\section{Casebeskrivelser}

På skole 1 anvendes de funktionelle læremidler af lærer 1 til at understøtte kommunikationen - og især til reception af tekst eller 
opgaver. Opgaverne vises på den interaktive tavle, og eleverne kan vælge at skrive deres besvarelse af opgaver på egen bærbare pc, der således anvendes som skrivemaskine. I en bevægelsesaktivitet, der fungerer som et break mellem to aktiviteter, skal eleverne bruge fysiske post-it-sedler til at skrive et pænt ord om hinanden og sætte det på kammeraternes ryg. Der er ikke tale om en konstitutiv øvelse, der underbygger eller udbygger elevernes forståelse af det faglige indhold, de er i gang med at arbejde med, men en additiv øvelse, der handler om, at eleverne skal røre sig. Valget af et analogt, funktionelt læremiddel understøtter lærerens mål om, at eleverne skal rejse sig fra stolene og bevæge sig frit rundt i klassen (post-it-sedlerne er reelt bærbare). Læreren italesætter ikke på noget tidspunkt eksplicit de funktionelle læremidler. De indgår upåfaldende som redskaber, lærere og eleverne anvender fra tid til anden.

Observationer af den samme lærer i de efterfølgende lektioner understøtter denne fortolkning. I case 2 skal eleverne arbejde med novellen "En æggesnaps" af Tove Ditlevsen (u.å.). I den forbindelse ser eleverne uddrag af et tv-program om forfatteren. Det vises på den interaktive tavle. Eleverne noterer på pc, men de løser også opgaver på papir med blyanter og andre skriveredskaber. Læreren rammesætter ikke brugen, der forekommer upåfaldende. I parallelklassen, case 3 sker undervisningen på samme måde: På den interaktive tavle vises både opgaver og tv-program, eleverne skriver på pc'er og i hånden. Ingen kommenterer dette eksplicit. Mens brugen af semantiske og didaktiske læremidler rammesættes af læreren, sker ingen rammesætning af de funktionelle læremidler.

I case 23 er endnu et eksempel på, at læreren ikke blot selv ibrugtager, men også lader eleverne ibrugtage funktionelle digitale læremidler upåfaldende og uden rammesætning. På den interaktive tavle er læreren logget ind på læringsplatformen "Min uddannelse". Læreren rammesætter meget kort dagens arbejde med en sms-novelle: "I skal tage jeres mobiler med ud i de her grupper. I skal ikke læse alle sms'erne igennem, men I skal opsummere, hvad denne her novelle handler om. Og så skal I skal kigge på de her arbejdsspørgsmål, som jeg har lagt ind på Min uddannelse" (case 23). Flertallet af eleverne sidder med en pc slået op på bordet foran sig. På pc'en tilgår eleverne opgaverne på Min uddannelse. I den fælles opsamling/klassesamtale spørger læreren imidlertid om, hvad eleverne synes om at få en novelle på denne måde. En elev mener, at man føler sig mere som hovedpersonen, mens andre elever mener, at forfatteren har skrevet novellen på sms, fordi vedkommende tror, at unge mennesker hele tiden tjekker deres mobil. Der tales ikke yderligere om, hvad det betyder, at novellen tilgås på mobiltelefonen. Både den interaktive tavle og mobiltelefonen fungerer som kommunikationskanaler, hvor 
eleverne receptivt kan tilgå tekst - selv når medie og tekstformat (SMS på mobil) er en central del af primærtekstens stil og udsigelse.

Vi har set flere eksempler på, at den interaktive tavle bruges til at vise et digitalt didaktisk eller semantisk læremiddel. I case 4, skal eleverne, som omtalt ovenstående, selv producere opgaver til teksten (didaktisere det semantiske læremiddel). I denne case fungerer den interaktive tavle - som i mange andre cases - til at vise det digitale læremiddel, som tilgås gennem læringsplatformen Min Uddannelse. I elevernes gruppearbejde med at producere spørgsmål til novellen arbejder nogle grupper på computer, andre med papir og blyant. Ingen bemærker denne forskel. Da grupperne skal udveksle opgaver/ arbejdsspørgsmål til teksten skal eleverne aflevere spørgsmålene på papir til makkergruppen. De grupper, der har arbejdet på pc, printer derfor deres spørgsmål. Som beskrevet indledningsvist i dette afsnit er en af de digitale informationsteknologiers affordances, (muligheder) at de kan understøtte videndelingsprocesser i undervisningen - og man kan derfor undre sig over, at denne affordance ikke udnyttes. Da samme lærer i en senere observation sætter eleverne i gang med et forløb i skriftlig fremstilling/novelleskrivning, rammesættes elevernes brug af funktionelle læremidler heller ikke.

En af de cases, hvor brugen af funktionelle læremidler italesættes mest eksplicit, finder vi i en case på skole 3, hvor læreren $\mathrm{i}$ begyndelsen af lektionen beder eleverne om at finde en blyant og deres computer eller andet, der kan gå på nettet, frem: "Hvis computeren skal have strøm, så sæt dem til med det samme, så vi ikke skal rode med det undervejs" (case 9). Hvor antagelsen tidligere har været, at læreren, når han eller hun inddrager it i undervisningen, altid må have en plan B, fordi man ikke kan være sikker på, at it virker (se eksempelvis Fougt, 2016), så ser vi en uproblematisk brug af it i undervisningen. I vores observationer ser vi ikke eksempler på, at it ikke virker; man kan måske ligefrem sige, at læreren ved at minde eleverne om, at computerne skal sættes til strøm, viser, at han foregriber potentielle "nedbrud" eller "roderi", og derved handler kompetent. I samme case (case 9) ses, at læreren anvender forskellige funktionelle læremidler, eksempelvis post-it-sedler, interaktiv tavle, whiteboard tavle og computere. Enkelte elever har ikke computer med og skriver derfor talenoter på mobiltelefon. I en anden case (case 20) er et eksempel på, at læreren eksplicit opfordrer eleverne til at anvende læse-skrive-teknologi; flere elever i klassen lytte-læser romanen "7.a.".

Vi ser kun få eksempler i de observerede cases på, at eleverne skal søge viden via internettet. I et arbejde med Jesper Wung Sungs roman "Kopierne" skal eleverne som nævnt oven for tilrettelægge en paneldebat om kloning (case 11). Som forberedelse til paneldebatten 
har eleverne læst forskellige artikler hjemme hentet på diverse hjemmesider, som læreren har udpeget. I undervisningen bruger eleverne hjemmesiderne til at finde gode argumenter for deres sag. Af observationerne fremgår ikke, om eller hvordan læreren har undervist eleverne i søgning. I en anden case fra en anden skole (case 14) arbejder eleverne med grammatik. De skal fremstille plancher (i fysiske materialer) med forskellige ordklasser. Når eleverne går i stå i deres beskrivelse, opfordrer læreren dem til at prøve at gå på nettet for at se, om de kan finde noget nyttigt.

I en enkelt case ser vi, at læreren fraråder eleverne at søge på nettet. Det gælder i en case, hvor eleverne skal arbejde med reklamer (case 16). Eleverne skal finde egne reklamer, som de skal arbejde med. Læreren har medbragt en stak blade: "Det der med at gå online, som vi så i går, da vi kiggede efter reklamer, det kan nogle gange godt være sådan lidt tvivlsomt, om det er det bedste, vi kan finde". Denne case er i det hele taget interessant i et læremiddel-perspektiv, fordi læreren, som beskrevet i det ovenstående, veksler mellem flere forskellige læremiddeltyper. Og fordi læreren som en af de få giver begrundelser, omend kortfattede, for valg af også funktionelle læremidler. I arbejdet med reklameanalyserne skal eleverne arbejde parvis og får at vide, at de skal arbejde i Office 365, så det giver mulighed for dokumentdeling og samskrivning. Her bruges og begrundes det funktionelle digitale læremiddel til at understøtte elevernes samarbejde og proces. Senere i samme lektion skal eleverne skrive diktat. I den forbindelse viser læreren eleverne på den interaktive tavle, hvordan de anvender digitale ordbøger. Eleverne har været inde på dem før, så de logger hurtigt ind. Ordbøgerne i sig selv er semantiske læremidler, men via brug af den interaktive tavle får læreren mulighed for at modellere elevernes mulige opslag. Det funktionelle digitale læremiddel anvendes således til at understøtte elevernes arbejdsproces.

Det er ikke overraskende, at der indgår funktionelle læremidler på den ene eller den anden måde i stort set alle casene. Eleverne sidder med deres computere, de henter opgaver fra for eksempel Min Uddannelse, de skriver på computer, søger på internettet og gemmer besvarelser, som lægges på læringsplatformen. Smartboardet er tændt i mange af de observerede lektioner. De hyppigst forekommende funktionelle læremidler er computeren og den interaktive tavle (som dog kun bruges som lærred).

Vedrørende de digitale funktionelle læremidler er det mest påfaldende fund den fuldkommen upåfaldende ibrugtagning, der sker af funktionelle digitale læremidler i de observerede cases. Hverken lærere eller elever bemærker, rammesætter eller sætter eksplicit spørgsmålstegn ved inddragelsen af de funktionelle læremidler.

Samtidig er det et centralt fund, at de funktionelle læremidler 
- ikke mindst de digitale funktionelle læremidler - især anvendes som distributionskanaler. Både computeren og den interaktive tavle anvendes i høj grad som kommunikationsredskaber, der gør læreres og elevers adgange til tekster, tv-programmer og arbejdsopgaver lettere.

Ikke mindst set i lyset af de sidste mange års initiativer for digitalisering af folkeskolen er den smalle brug af især de funktionelle digitale læremidler overraskende. Siden 2000 har været gennemført en række politisk initierede satsninger for at styrke it i folkeskolen, og der er fra 2000-2017 blevet investeret næsten halvanden milliard kroner i pædagogisk anvendelse af it i folkeskolen (Hansen, 2016, s. 18). Når vi karakteriserer brugen som 'smal', betyder det både, at der inddrages få forskellige funktionelle læremidler, og at brugen heraf er ensidig. De funktionelle digitale læremidler kan potentielt set understøtte mange forskellige funktioner i undervisningen, men vi ser stort set kun, at lærere og elever anvender læremidlerne til distribution og kommunikation af indhold. En receptiv frem for en produktiv brug.

\section{Sammenfatning og diskussion}

I artiklen har vi brugt de tre læremiddeltyper, didaktiske, semantiske og funktionelle læremidler, som begrebsligt afsæt for at kategorisere de observerede læremidler og analysere lærernes brug af dem. Især mht. til skellet mellem didaktiske og semantiske læremidler synes grænsen at være svær at trække, når vi beskæftiger os med lavt didaktiserede, didaktiske læremidler. En enkeltstående ressource, som for eksempel et analyseskema til reklamefilm, er sandsynligvis produceret med henblik på at indgå i undervisning, men da læremidlet kun repræsenterer indhold (analytiske begreber og kategorier), lægger det sig tæt op ad et semantisk læremiddel.

Vi har valgt at medtage disse læremidler med meget lav didaktiseringsgrad under didaktiske læremidler velvidende at eksempelvis Hansen (2012) ville kategorisere disse som semantiske læremidler. Det gør vi for at betone, at der i disse tekster er en didaktisk intentionalitet, idet en afsender har udvalgt og præsenteret indhold på en måde, der egner sig til undervisningsbrug - om end denne intentionalitet er snæver.

Vi har valgt en løsning, hvor vi ved, de lavt didaktiserede læremidler taler om behovet for didaktisering af de didaktiske funktioner, som det lavt didaktiserede læremiddel ikke beskæftiger sig med - og eventuel redidaktisering af de områder som lære- 
midlet indeholder bud på operationalisering af. Vi finder imidlertid ikke mange eksempler på substantiel redidaktisering; for eksempel ser vi ikke et eneste redidaktiserende tiltag for at undervisningsdifferentiere.

Netop studiet af lærerens aktualisering af det didaktiske potentiale i læremidlet bidrager med ny og interessant viden om en palet af transformationer, der foregår, når lærere tager et læremiddel i anvendelse. Vi ser således et højtdidaktiseret læremiddel, der bruges som semantisk læremiddel (case 4, og 5), lavt didaktiserede, enkeltstående ressourcer, der qua en lav grad af rammesætning fra læreren anvendes som om de var højt didaktiserede læremidler (for eksempel case 20 og 21), men også brug af højt didaktiserede læremidler, der er tro mod det intenderede didaktiske design i læremidlet (for eksempel case 6, 7 og 23).

Specielt omfanget af brugen af lavt didaktiserede, enkeltstående ressourcer samt den manglende rammesætning af disse læremidler har overrasket os. Arbejdsark bruges som didaktiske læremidler, dvs. som om de varetager alle relevante didaktiske funktioner og ikke kræver yderligere rammesætning fra lærerens side. De ibrugtages i stort omfang. Uden det didaktiske supplement fra lærerens side, overlades didaktiseringen til eleverne selv, der udfører opgaverne med en rutine, der formentlig kan tilskrives deres kendskab til skolens rutiner. Kun sjældent stiller eleverne spørgsmål til læreren i forhold til, hvad der forventes af dem, også selvom rammesætning og didaktisering fra lærerens side er svag. Her er det vigtigt at holde sig for øje, at vi kun har adgang til ganske få observationer pr. klasse; vi kender ikke klassens rutiner og har ikke kunnet spørge ind til lærernes refleksioner og bevæggrunde for deres undervisning. Det er derfor en mulighed, at eleverne er klar over, hvorfor de udfører bestemte aktiviteter, og hvordan de skal gøre det fra tidligere lektioner. Men det er afgørende, at man i læreruddannelsen ikke kun fokuserer på at klæde de studerende læremiddeldidaktisk på til at forholde sig refleksivt til højt didaktiserede læremidler, men også beskæftiger sig med lavt didaktiserede enkeltstående ressourcer.

Observationerne viser, at semantiske læremidler fylder forholdsvist meget i den observerede undervisning. Vi finder, at de semantiske læremidler, lærerne tager i brug, primært er repræsenteret ved æstetiske tekster. Bundsgaard, Buch og Fougt (2017) viser i deres undersøgelse af læremidler, at litteratur og litteraturanalyse er det indholdsområde, der fylder mest i de didaktiske læremidler i udskolingen. Det samme kan siges at gøre sig gældende i forhold til de semantiske læremidler i den undervisning, vi har observeret. Lærerne vælger ofte at læse noveller og romaner, både klassikere, for eksempel Tove Ditlevsen, og tekster af nyere karakter, 
for eksempel Daniel Zimakoff og Jesper Wung-Sung - og primært børne- og ungdomslitteratur.

Da vi ikke har interviewet lærerne, ved vi ikke, hvilke overvejelser de har gjort sig om didaktiseringen af de semantiske læremidler, men med udgangspunkt i de tre ovennævnte begreber (legitimering, repræsentation og lærbarhed) kan teksterne siges både at have potentiale til at udvikle elevernes viden om tekster, deres analytiske og fortolkningsmæssige kompetence samt styrke deres dannelsesmæssige udvikling. Stoffet må siges at være lærbart, da sprog og tematik er rettet mod målgruppen. Overordnet set er der to temaer i spil i valget af de æstetiske tekster, som vi ser i observationerne, nemlig "barndom/ungdom" og "Gys og gru”. Begge temaer må forventes at appellere til målgruppen. Bundsgaard, Buch og Fougt (2017) viser også i deres undersøgelse, at der ikke er ligevægt mellem analysearbejdet og fortolkningsarbejdet i arbejdet med æstetiske tekster i de didaktiske læremidler, lærere vælger at bruge. Det samme billede tegner sig i vores cases, hvor lærerne benytter semantiske læremidler. Her anvendes ofte didaktiserede analyseskemaer med fokus på analysedelen sammen med det semantiske læremiddel. Lærerne anvender således langt hen ad vejen de semantiske læremidler med samme analytiske fokus som findes i de didaktiske læremidler.

Vi ser også eksempler på inddragelse af praktiske tekster som semantiske læremidler, eksempelvis avisartikler, taler, reklamer og personlige videokanaler på YouTube. De praktiske tekster er tilsyneladende (ligesom de fiktive tekster) valgt med udgangspunkt i, hvad børn/unge mennesker er optaget af og møder i hverdagen, for eksempel YouTube, reklamer og DR Ultra. Også her må man formode, at indholdet og formen appellerer til målgruppen og stoffet er lærbart.

De semantiske læremidler spiller således en væsentlig rolle i danskundervisningen og har betydning både for elevernes faglige læring samt deres personlige og kulturelle identitet. Inddragelse af semantiske læremidler er en oplagt måde, hvormed læreren kan præsentere eleverne for flere og andre tekster end dem, der findes i de didaktiske læremidler og dermed give eleverne flere perspektiver på en given problemstilling. Det er netop skolens ansvar at klæde eleverne på til at læse forskellige tekster med forskellige formål, så eleverne tilegner sig en bred literacy-kompetence. De semantiske læremidler kan være med til at bygge bro mellem elevernes tekstkultur, deres fritid, og skolens tekstkultur, hvorved faget kan opleves som mere relevant (Blikstad-Balas, 2019). Samtidig er det at udvide tekstrepertoiret en helt central del af det at forholde sig kritisk til tekster. Det kræver dog, at læreren bruger teksterne til faglige formål og taler om dem på en faglig måde (Blikstad-Balas, 2019). I 
casene ser vi, hvordan lærerne bruger de semantiske læremidler, både æstetiske tekster og brugstekster, sammen med enkeltstående ressourcer. Konsekvensen er, at fokus rettes mod analysen og knap så meget mod fortolkningen (for eksempel case 12, 13 og 16), eller samtalerne foregår mere uformelt som for eksempel i case 12, hvor læremidlet didaktiseres løbende på baggrund af elevernes input. En mere tydelig og målrettet didaktisering af de semantiske læremidler fra lærerens side kunne have styrket det danskfaglige og kritiske perspektiv på teksterne.

Når det gælder funktionelle læremidler, er det mest overraskende fund, at de indgår upåfaldende i undervisningen, samt at især de digitale funktionelle læremidler overvejende understøtter receptive aktiviteter. Begge disse fund giver anledning til undren og yderligere diskussion.

I det tværgående tema "It og medier" opereres med fire elevpositioner: 1. Eleven som kritisk undersøger, 2. Eleven som analyserende modtager, 3 . Eleven som målrettet og kreativ producent og 4. Eleven som ansvarlig deltager (Undervisningsministeriet, 2020). Elevpositionerne beskriver måder, som eleverne forventes at arbejde på - og som funktionelle digitale læremidler forventes at understøtte. Det er bemærkelsesværdigt, at vi stort set ikke ser eksempler på, at de funktionelle digitale læremidler inddrages på denne måde. Med revisionen af Foelles Mål i 2013/14 blev skrivning som kompetenceområde erstattet af begrebet "Fremstilling". Ændringen understreger, at elever i dag også skal lære at formulere sig i multimodale tekster med brug af andre repræsentationsformer end den sproglige. Hvorfor? Et argument er fagenes forskellige udtryksmåder. Ikke alene har fagene forskelligt fagsprog, men man bruger også repræsentationsformer som billeder og diagrammer på en anden måde i matematik end i dansk. Og inden for danskfaget er der forskel på at vise en begivenhed i billeder eller diagrammer i en nyhedsartikel eller bruge billeder til at give udtryk for fortolkning af en novelle.

Men der kan også være andre gode grunde til at diskutere den manglede kreative brug af især digitale funktionelle læremidler. Igennem de sidste 10 år har mange med henvisning til bl.a. Selander \& Kress (2012) peget på, at mere kreativt, skabende og multimodalt arbejde kan styrke elevernes dybdelæring. Specifikt når det drejer sig om didaktiske tiltag, der har betydning for elevers følelsesmæssige indlevelse og faglige engagement peges der i eksisterende forskning på, at kreativ produktion støttet af teknologi kan bruges til at fremme en skabende undersøgelse af litteratur (Elf \& Hansen, 2017, s. 106). Mange skoler har adgang til www.skoletube.dk, og vi havde forventet, at lærere og elever i danskundervisningen ville arbejde mere kreativt 
med mange repræsentationsformer med brug af forskellige apps; at der i danskundervisningen havde udviklet sig en kulturel praksis, hvor multimodal elevproduktion stod stærkere.

Endelig er det overraskende, at læreren ikke italesætter brug af læremidlerne - herunder forskellige funktionelle læremidlers muligheder og begrænsninger. Eleverne skal i skolen og i danskfaget også lære at vælge og vurdere, hvilke redskaber, der giver dem mulighed for at udtrykke sig på måder, som er hensigtsmæssige i situationen - nogle gange sker det med papir og blyant eller ved at lave en collage med udklip fra dameblade. Andre gange sker det med digital multimodal produktion af en bog eller en hjemmeside.

\section{Referencer}

Atjonen, P., Halinen, I., Hämäläinen, S., Korkeakoski, E., Knubb-Manninen, G. \& Kupari, P. (2008). Tavoitteista vuorovaikutukseen. Perusopetuksen pedagogiikan arviointi [From aim to interaction. An Evaluation of the Pedagogy of the Comprehensive Education in Finland]. Jyväskylä: Koulutuksen arviointineuvoston julkaisuja, 3 .

Blikstad-Balas, M. (2019): Literacy i skolen. Universitetsforlaget.

Borstrøm, I., Petersen, D. K. \& Elbro, C. (1999). Hvordan kommer børn bedst i gang med at lcese? Center for Læseforskning, Undervisningsministeriets forlag.

Bundsgaard, J., Buch, B. \& Fougt, S. S. (2017). De anvendte læremidlers danskfag belyst kvantitativt. I: J. Bremholm, J. Bundsgaard, S. S. Fougt, \& A. K. Skyggebjerg (red.), Loeremidlernes danskfag (s. 28-54). Aarhus Universitetsforlag.

Bundsgaard, J. \& Hansen, T. I. (2011). Holistic evaluations of learning materials. I: J. R. Rodríguez, M. Horsley, \& S. V. Knudsen (red.), Local, national and transnational identities in textbooks and educational media: 10th International Conference on Research on Textbooks and Educational Media September 2009 Santiago de Compostela - Spain (s. 502-520). IARTEM. http://www.iartem.no/ documents/X_Conference_Textbooks_IARTEM_155x235_HD.pdf

Børne- og Undervisningsministeriet. (2019). Dansk. Faghoefte - Fcelles Mål, loeseplan og vejledning 2019. https://emu.dk/grundskole/dansk/faghaefte-faelles-maallaeseplan-og-vejledning

Carlsen, D. \& Hansen, J. J. (2009). At vurdere loeremidler i dansk. Dansklærerforeningens Forlag. Studieserien.

Elf, N. F. \& Hansen, T. I. (2017). Forundersøgelse i projekt Kvalitet $i$ Dansk og Matematik: Hvad vi ved om undersøgelsesorienteret undervisning i dansk. Og hvordan vi kan bruge denne viden til at skabe bedre kvalitet $i$ danskfagets litteraturundervisning i grundskolen. Læremiddel.dk. 
Fälth, L. (2013). The use of interventions for promoting reading development among struggling readers [Doctoral dissertation, Linnaeus Universitet, Växjö]. Linnaeus University Dissertations No 123/2012. https://www.spsm.se/globalassets/ funktionsnedsattning/avhandlingar/the-use-of-interventions-for-promotingreading-development-among-struggling-readers-falt-linda.pdf

Gilje, Ø., Ingulfsen, L., Dolonen, J. A., Furberg, A., Rasmusse, I., Klug, A., Knain, E., Mørch, A., Naalsund, M. \& Skarpaas, K. G. (2016). Med ARKEAPP. Bruk av loeremidler og ressurser for loering på tvers av arbeidsformer [With paper \& App. Use of teaching and learning materials and resources for learning across working methods]. Universitetet i Oslo.

Gilje, Ø. (2016). På jakt etter ark og app i fire fag i det nye norske læremiddellandskapet. Learning Tech, 1(1), 36-61. https://doi.org/10.7146/ lt.vii1.107619

Gissel, S. T. \& Buch, B. (2020). A systematic review of research on how students and teachers use didactic learning materials in L1. Learning Tech, 7, 90-129.

Gissel, S. T. \& Skovmand, K. (2018). Kategorisering af digitale loeremidler. En undersøgelse af didaktiske, digitale loeremidlers karakteristika. Læremiddel.dk. http://laeremiddel.dk/wp-content/uploads/2018/o5/Kategorisering-af-digitalel\%C3\%A6remidler.pdf

Hacker, H. (1980). Didaktische Funktionen des Mediums Schulbuch. I: H. Hacker (red.), Das Schulbuch. Funktion und Verwendung im Unterricht. Klinkhardt.

Hansen, J. J. (2006). Mellem design og didaktik: Om digitale loeremidler i skolen. Syddansk Universitet. Det Humanistiske Fakultet.

Hansen, J. J. (2010). Loeremiddellandskabet. Fra loeremiddel til undervisning. Akademisk Forlag.

Hansen, J. J. (2012). Dansk som undervisningsfag: Perspektiver på design og didaktik. Dansklærerforeningen.

Hansen, J. J. \& Gissel, S. T. (2019). Danskfaget i spil på læringsplatforme. Learning Tech - Tidsskrift for loeremidler, didaktik og teknologi, (6), 176-199. DOI 10.7146/ lt.v4i6.110884

Hansen, R. \& Carlsen, D. (2017). Videoobservation - et empirisk blik på undervisning. Studier i loereruddannelse og -profession, 2(1), 47-72

Hansen, T. I. (2010): It og medier i et læremiddelperspektiv. KvaN, 30(86), 105-116.

Hansen, T. I. \& Skovmand, K. (2011). Folles mål og midler. Loeremidler og loereplaner $i$ teori og praksis. Klim.

Hansen, T. I. \& Bundsgaard, J. (2013). Kvaliteter ved digitale loeremidler og ved poedagogiske praksisser med digitale loeremidler [Qualities of digital learning materials and pedagogical practices with digital learning materials]. Undervisningsministeriet.

Hansen, T.I. (2015). Dansk. Klim.

Hansen, T. I., Elf, N. F., Misfeldt, M., Gissel, S. T. \& Lindhardt, B. K. (2020). Kvalitet $i$ dansk og matematik: Et lodtrcekningsfors $\emptyset$ med fokus på undersøgelsesorienteret dansk-og matematikundervisning. Læremiddel.dk.

Houang, R. T. \& Schmidt, W. H. (2008). “TIMSS International Curriculum Analysis and Measuring Educational Opportunities”. I: 3rd IEA International Research Conference TIMSS. 3rd IEA International Research Conference. 
Jank, W. \& Meyer, H. (1997). Sambandet mellan didaktisk teorikunskap och handlingskompetens. I: Uljens, M. (red.), Didaktik (s. 35-46). Studentlitteratur.

Kabel, K. (2020). For what benefit? Grammar teaching materials in upper primary Danish L1. L1-Educational Studies in Language and Literature, (20), 1-25.

Knudsen, S. V. (Ed.). (2011): Internasjonal forskning på loeremidler - en kunnskapsstatus. Høgskolen i Vestfold. https://www.udir.no/Upload/ Rapporter/2012/laremidler_hive.pdf

Krogh, E. (2003). Et fag i moderniteten: Danskfagets didaktiske diskurser. Syddansk Universitet. Det Humanistiske Fakultet.

Krogh, E. (2011). Undersøgelser af fag i et fagdidaktisk perspektiv. Cursiv, 7, 33-49.

Krogh, E., Elf, N. F., Høegh, T. \& Rørbech, H. (2017). Fagdidaktik $i$ dansk. Frydenlund Academic. Didaktik.

Mullis, I. V., Martin, M. O., Foy, P. \& Arora, A. (2012). TIMSS 2011 international results in mathematics. TIMSS \& PIRLS International Study Center.

Pettersson, M., Hansen, T. I., Kølsen, C. \& Bundsgaard, J. (2016). Loereres praksis Data fra loerersurvey i AUUC-konsortiets demonstrationsskoleprojekter. Teknisk rapport. AUUC. http://www.auuc.demonstrationsskoler.dk/forskningsprojekter/ effektmåling/rapporter-og-bilag/læreres-praksis-data-fra-lærersurvey-i-auuc

Rambøll Management \& Boston Consulting Group. (2014). Anvendelse af digitale loeremidler. Effektmåling [The use of digital learning materials: Power measurement]. Undervisningsministeriet. https://www.uvm.dk/-/media/filer/ uvm/udd/folke/pdf13/sep/130927-forskningsrapport-effektmaaling.pdf

Rørbech, H. (2016). Mellem tekster: Kultur og identitet i klasserummet. Samfundslitteratur.

Selander, S. \& Kress, G. (2012). Lceringsdesign - i et multimodalt perspektiv. Frydenlund.

Sigurgeirsson, I. (1992). The role, use and impact of curriculum materials in intermediate level Icelandic classrooms [Doctoral dissertation, University of Sussex, Brighton].

Slot, M.F. (2010). Lceremidler i danskfaget En undersøgelse af gymnasieelevers og loereres brug af tre loeremidler $i$ danskfaget - set i relation til udvikling af tekstkompetence [ph.d.-afhandling]. Lokaliseret på https://www.sdu.dk/-/media/ files/forskning/phd/phd_hum/afhandlinger/2010/marie+falkesgaard+slot.pdf

Valverde, G. A., Bianchi, L. J., Wolfe, R. G., Schmidt, W. H. \& Houang, R. T. (2002). According to the book: using TIMSS to investigate the translation of policy into practice through the world of textbooks. Kluwer Academic Publishers.

Wikman, T. \& Horsley, M. (2012). Down and up: Textbook research in Australia and Finland. IARTEM eJournal, 5(1), 45-53.

\section{Referencer læremidler}

Andersen, B. \& Dissing, P. (u.å.). Svantes lykkelige dag. Videoklip på Youtube.

Beckmann, G. (2002). Alene hjemme. I: L. Olsen-Bülow, V. Skaarup \& K. S. Harms. Tid til dansk 7. kl.: Luk vinduet op, Læsebog. Alinea (s. 202-220).

Debat med mening (u.å.). https://www.debatmedmening.dk/

Det Danske Kongehus (2018). Kronprinsessens tale til Kronprinsen. https://www. youtube.com/watch?v=RPimuroaI8Q

Det etiske råd (u.å.). https://www.etiskeraad.dk/ 
Ditlevsen, T. (1997). En ceggesnaps - og andre noveller. Gyldendal.

DR (2018). Mick Øgendahl og de store forfattere. https://www.dr.dk/skole/dansk/ udskoling/tema/oegendahl-og-de-store-forfattere

DR (u.å.). Ultranyt. https://www.dr.dk/ultra/ultranyt

Gyldendal (2008). Gyldendals Retskrivningsordbog. Gyldendals Røde Ordbøger. Gyldendal.

Gyldendal (u.å.). Hos regnormene. Skriftlig fremstilling 7-9. Gyldendal. https:// skriftligfremstilling.gyldendal.dk/opgavebase/7-klasse

Hagen, J. Z. (u.å.). Scetninger. Dansk.Gyldendal.dk. https://cms-pm1.gyldendal.dk/ Dansk/Indgange/forloeb/sprog/saetninger.aspx

Hansen, T. V. A., \& Jessen, H. (u.å.). Reklamebillede. Indidansk.dk. https://indidansk. $\mathrm{dk} /$ reklamebillede

Hundebøl, M. \& Therkildsen, B. (u.å.-a). ”Træn din skrivemuskel”. MB dansk. https://sites.google.com/view/mb-dansk/startside

Hundebøl, M. \& Therkildsen, B. (u.å.-b). "Skriv en keeeedelig tekst". MB dansk. https://sites.google.com/view/mb-dansk/startside

Hundebøl, M. \& Therkildsen, B. (u.å.-c). ”Skriv, hvad tavlen spekulerer på”. MB dansk. https://sites.google.com/view/mb-dansk/startside

Hundebøl, M. \& Therkildsen, B. (u.å.-d). "Skriv en hilsen til dig selv - i morgen”. MB dansk. https://sites.google.com/view/mb-dansk/startside

Husum, A. (u.å.) Alexander Husum [YouTube channel]. https://www.youtube.com/ channel/UCy_FdfBF-YReHm5NYnZ7zcA

Jensen, L. (2014). Rejsen til min far. Gyldendal.

Joost, T. (2017). Kopierne - grafisk roman. Center for Undervisningsmidler. http:// mitcfu.dk/pv/51616588.pdf

Holmberg, L. (u.å.). Loerke Holmberg [YouTube channel]. https://www.youtube.com/ channel/UCOJV829eKWHeWyGMegwgIUw

May, T. \& Arne-Hansen, S. (2013). Fandango 7 - Vinkler på dansk. Gyldendal.

Montanari, R. (25. februar, 2006). Ikke rigtigt voksne, ikke rigtigt børn. Kristeligt Dagblad. https://www.kristeligt-dagblad.dk/danmark/ikke-rigtigt-voksne-ikkerigtigt-børn

Nielsen, K., Nielsen, H. \& Jensen, H. S. (2005, 3. udg.) Skruen uden ende: Den vestlige teknologis historie. København: Nyt Teknisk Forlag.

Olsen, A. (1998). Balladen om T.T.T. Videoklip på Youtube.

Olsen-Bülow, L., Skaarup, V. \& Harms, K. S. (2002). Tid til dansk 7. kl: Luk vinduet op, Loesebog. Alinea (s. 202-220).

Pedersen, L. \& Tingleff, S. (u.å.). Sms-novellen "Efter festen". CLIO. https:// portals.clio.me/dk/dansk/7-10/forloeb/show-unitplan/?unit_plan=d5dbd75ea146-4764-8fd4-56f98a949odc\&navigation=introduction\&is_ preview=1\&cHash=b603c8f64aaccbeae63e5f8afb9a296c

Politiske-Memes.dk (2014). Lars Løkke Rasmussen forklarer hvad han mener. Youtube. https://www.youtube.com/watch?v=pRFuhQQnjXM

Simonsen, R. T. (u.å.). Efter festen. SMSpress.dk.

Svenningsen, M. (u.å.): Boeredygtig konfirmation. Loerke skal konfirmeres i en brugt kjole 
Sørensen, B. (2016). Dansk og dannelse - i et historisk perspektiv. Dansk 2(16). lokaliseret 23. august, 2017, på https://issuu.com/dansklf/docs/dansk_2_2016_ epage

Videnskab.dk (u.å.) https://videnskab.dk

Vognstoft.dk (u.å.). Bjarne Reuter: 7.a. http://www.vognstoft.dk/danskopg/7.a/ bjarne_reuter_7a_l_sning.doc

Westergaard, M. B. (2018). Kviksand. Center for Undervisningsmidler. https://hval. $\mathrm{dk} / \mathrm{mitcfu} /$ materialeinfo.aspx idnr=CFUEBOG1074911\&cfuid $=14$,

Wung-Sung, J. (2010). Kopierne. Høst \& Søn. 


\section{Appendiks}

\section{Appendiks A.}

Oversigt over cases, skole, lærer og lektionsnummer samt hvordan de tre typer læremidler var repræsenteret $i$ hver case.

\begin{tabular}{|c|c|c|c|c|}
\hline Case \# & $\begin{array}{l}\text { Skole, lærer og } \\
\text { lektion \# }\end{array}$ & Didaktiske læremidler & Semantiske læremidler & Funktionelle læremidler \\
\hline 1 & $\mathrm{~S} 1, \mathrm{~L} 1, \mathrm{~T} 1$ & $\begin{array}{l}\text { Arbejdsark: "Træn din } \\
\text { skrivemuskel" (Hundebøl \& } \\
\text { Therkildsen, u.å.-a), (DL1). } \\
\text { Arbejdsark: "Skriv } \\
\text { en keeeedelig tekst" } \\
\text { (Hundebøl \& } \\
\text { Therkildsen, u.å.-b), (DL2). } \\
\text { Ordkendskabsopgave } \\
\text { som arbejdsark, ukendt } \\
\text { oprindelse, (DL3). } \\
\text { Opgaver til sagteksten } \\
\text { ses kun på IWB, ukendt } \\
\text { oprindelse, (DL4). }\end{array}$ & $\begin{array}{l}\text { Artikel fra Kristeligt } \\
\text { Dagblad (2006): Ikke rigtigt } \\
\text { voksne, ikke rigtigt børn. }\end{array}$ & $\begin{array}{l}\text { Interaktivt whiteboard (IWB) } \\
\text { PC'er } \\
\text { Papir og blyant } \\
\text { Post-it-sedler }\end{array}$ \\
\hline 2 & $\mathrm{~S} 1, \mathrm{~L} 1, \mathrm{~T} 2$ & $\begin{array}{l}\text { Arbejdsark: "Skriv, } \\
\text { hvad tavlen spekulerer } \\
\text { på" (Hundebøl \& } \\
\text { Therkildsen, u.å.-c), (DL5). }\end{array}$ & $\begin{array}{l}\text { Ultranyt fra dr.dk } \\
\text { Klip fra DR1: Mick Øgendahl } \\
\text { og de store forfattere. Lyden } \\
\text { er desværre mistet på denne } \\
\text { del af optagelsen) } \\
\text { Kristeligt Dagblad 2006: Ikke } \\
\text { rigtigt voksne, ikke rigtigt børn. }\end{array}$ & $\begin{array}{l}\text { IWB } \\
\text { PC'er } \\
\text { Papir og blyant } \\
\text { Kopper, sukker, æg, teskeer }\end{array}$ \\
\hline 3 & $\mathrm{~S} 1, \mathrm{~L} 2, \mathrm{~T} 1$ & $\begin{array}{l}\text { Arbejdsark: "Skriv en } \\
\text { hilsen til dig selv - i } \\
\text { morgen" (Hundebøl \& } \\
\text { Therkildsen, u.å.-d), (DL6). }\end{array}$ & T. Ditlevsen: En æggesnaps. & $\begin{array}{l}\text { White board } \\
\text { PC'er } \\
\text { Blyant og papir } \\
\text { Kopper, sukker, æg, teskeer }\end{array}$ \\
\hline 4 & $\mathrm{~S} 2, \mathrm{~L} 1, \mathrm{~T} 1$ & $\begin{array}{l}\text { Tid til dansk. Luk vinduet op. } \\
\text { Læsebog } 7 \text { (Olsen-Bülow, } \\
\text { Skaarup \& Harms, 2002), } \\
\text { (DL7). }\end{array}$ & & $\begin{array}{l}\text { IWB } \\
\text { PC'er } \\
\text { Papir + blyant } \\
\text { Printer }\end{array}$ \\
\hline 5 & $\mathrm{~S} 2, \mathrm{~L} 1, \mathrm{~T} 2$ & $\begin{array}{l}\text { Tid til dansk. Luk vinduet op. } \\
\text { Læsebog } 7 \text { (Olsen-Bülow, } \\
\text { Skaarup \& Harms, 2002), } \\
\text { (DL7). }\end{array}$ & & $\begin{array}{l}\text { IWB } \\
\text { PC'er }\end{array}$ \\
\hline 6 & S2, L1, T3 & $\begin{array}{l}\text { Forløbet "Hos regnormene" } \\
\text { (Gyldendal, u.å..) } \\
\text { fra Gyldendals fagportal til } \\
\text { dansk, 7. Klasse, (DL8). }\end{array}$ & & $\begin{array}{l}\text { IWB } \\
\text { PC'er }\end{array}$ \\
\hline
\end{tabular}




\begin{tabular}{|c|c|c|c|c|}
\hline 7 & $\mathrm{~S} 2, \mathrm{~L} 1, \mathrm{~T} 3$ & $\begin{array}{l}\text { Forløbet "Hos regnormene" } \\
\text { (Gyldendal, u.å..) } \\
\text { fra Gyldendals fagportal til } \\
\text { dansk, 7. Klasse, (DL8). }\end{array}$ & & $\begin{array}{l}\text { IWB } \\
\text { PC'er }\end{array}$ \\
\hline 8 & S3, L1, T1 & $\begin{array}{l}\text { Ark med oversigt over de } \\
\text { tre appelformer beskrevet } \\
\text { og eksemplificeret (ukendt } \\
\text { oprindelse), (DL9). } \\
\text { Lærerproduceret figur på } \\
\text { WB, der viser udvalgte } \\
\text { retoriske analyseelementer, } \\
\text { (DL10). }\end{array}$ & $\begin{array}{l}\text { Balladen om T.T.T. med/af } \\
\text { Allan Olsen } \\
\text { Svantes lykkelige dag med } \\
\text { Povl Dissing, meget kort } \\
\text { videoklip } \\
\text { Video af Kronprinsesse } \\
\text { Marys tale til Frederiks 50- } \\
\text { års fødselsdag }\end{array}$ & $\begin{array}{l}\text { Post-it-sedler Blyanter + } \\
\text { papir } \\
\text { PC'er } \\
\text { Mobiltelefoner } \\
\text { IWB } \\
\text { Whiteboard (WB) }\end{array}$ \\
\hline 9 & S3, L1, T2 & $\begin{array}{l}\text { Ark med oversigt over de } \\
\text { tre appelformer beskrevet } \\
\text { og eksemplificeret (ukendt } \\
\text { oprindelse), (DL11). }\end{array}$ & $\begin{array}{l}\text { Video med uddrag af Lars } \\
\text { Løkke Rasmussen-tale fra } \\
\text { Folketingets talerstol } \\
\text { Video med en ukendt } \\
\text { konfirmand (fra Youtube, kan } \\
\text { ikke genfindes) }\end{array}$ & $\begin{array}{l}\text { PC'er } \\
\text { Mobiltelefoner } \\
\text { IWB } \\
\text { WB } \\
\text { Post-it-sedler }\end{array}$ \\
\hline 10 & S4, L1, T1 & & $\begin{array}{l}\text { Jesper Wung- } \\
\text { Sung: Kopierne (2010) } \\
4 \text { hjemmesider: } \\
\text { Etiskråd.dk } \\
\text { Videnskab.dk } \\
\text { Debatmedmening.dk } \\
\text { Kristeligtdagblad.dk } \\
\text { Video om appelformer }\end{array}$ & $\begin{array}{l}\text { PC'er } \\
\text { IWB+tuscher } \\
\text { Papirskilte med gruppernes } \\
\text { navne }\end{array}$ \\
\hline 11 & S4, L1, T2 & & $\begin{array}{l}\text { Jesper Wung-Sung: Kopierne } \\
\text { (2010) } \\
4 \text { hjemmesider: } \\
\text { Etiskråd.dk } \\
\text { Videnskab.dk } \\
\text { Debatmedmening.dk } \\
\text { Kristeligtdagblad.dk }\end{array}$ & $\begin{array}{l}\text { WP } \\
\text { Projektor } \\
\text { Flipover } \\
\text { Tuscher } \\
\text { PC'er }\end{array}$ \\
\hline 12 & S4, L1, T3 & & $\begin{array}{l}\text { Jesper Wung-Sung: Kopierne } \\
\text { (2010) } \\
4 \text { hjemmesider: } \\
\text { Etiskråd.dk } \\
\text { Videnskab.dk } \\
\text { Debatmedmening.dk } \\
\text { Kristeligtdagblad.dk }\end{array}$ & $\begin{array}{l}\text { WP } \\
\text { Projektor } \\
\text { Flipover } \\
\text { Tuscher } \\
\text { PC'er }\end{array}$ \\
\hline 13 & S4, L2, T1 & $\begin{array}{l}\text { "Kopierne - grafisk roman" } \\
\text { (Joost, 2017), pædagogisk } \\
\text { vejledning udviklet af CFU, } \\
\text { (DL12). }\end{array}$ & $\begin{array}{l}\text { Jesper Wung Sung: Kopierne } \\
\text { (2010) }\end{array}$ & PC'er \\
\hline 14 & $\mathrm{~S} 4, \mathrm{~L} 2, \mathrm{~T} 2$ & Opgaveark, (DL 13). & $\begin{array}{l}\text { Jesper Wung Sung: Kopierne } \\
\text { (2010) }\end{array}$ & $\begin{array}{l}\text { WB } \\
\text { PC'er } \\
\text { Pap } \\
\text { Farver }\end{array}$ \\
\hline
\end{tabular}




\begin{tabular}{|c|c|c|c|c|}
\hline 15 & S4, L2, T3 & & $\begin{array}{l}\text { Louis Jensen: Rejsen til min } \\
\text { far (2014) }\end{array}$ & PC'er \\
\hline 16 & $\mathrm{~S} 5, \mathrm{~L} 1, \mathrm{~T} 1$ & $\begin{array}{l}\text { "Reklamebillede" (Hansen, } \\
\text { T.V.A \& Jessen, } \\
\text { H., u.å.), netressource om } \\
\text { reklamer og } \\
\text { reklameanalyse, (DL14). } \\
\text { Arbejdsark med diktat- } \\
\text { opgaver, (DL15). } \\
\text { Grammatip.dk (kun en } \\
\text { elev), (DL16a). }\end{array}$ & $\begin{array}{l}\text { Digitale reklamer fundet på } \\
\text { nettet } \\
\text { Reklamer fundet i ugeblade } \\
\text { Den røde ordbog (digitalt) }\end{array}$ & $\begin{array}{l}\text { PC'er } \\
\text { IWB } \\
\text { Office } 365 \\
\text { Blyanter } \\
\text { Viskelæder }\end{array}$ \\
\hline 17 & S5, L1, T2 & $\begin{array}{l}\text { Netressource om reklamer } \\
\text { og reklameanalyse, (DL17). } \\
\text { PDF med quiz og byt med } \\
\text { reklame-begreber, (DL18). }\end{array}$ & Frilæsningsbøger & $\begin{array}{l}\text { PC'er } \\
\text { IWB }\end{array}$ \\
\hline 18 & $\mathrm{~S} 5, \mathrm{~L} 2, \mathrm{~T} 1$ & $\begin{array}{l}\text { "Vi læner os tilbage } \\
\text { mod muren" (May } \\
\text { \& Arne-Hansen, } \\
\text { 2013) fra Fandango } 7 \text { - } \\
\text { Vinkler på dansk, (DL19a). }\end{array}$ & Frilæsningsbøger & $\begin{array}{l}\text { PC'er } \\
\text { IWB }\end{array}$ \\
\hline 19 & $\mathrm{~S} 5, \mathrm{~L} 2, \mathrm{~T} 2$ & $\begin{array}{l}\text { "Vi læner os tilbage } \\
\text { mod muren" (May \& } \\
\text { Arne-Hansen, 2013) } \\
\text { fra Fandango } 7 \text { - Vinkler på } \\
\text { dansk, (DL19a). }\end{array}$ & $\begin{array}{l}\text { Artikel om } \\
\text { bæredygtig konfirmation: } \\
\text { Maja Svenningsen: } \\
\text { "Bæredygtig konfirmation. } \\
\text { Lærke skal konfirmeres i en } \\
\text { brugt kjole" }\end{array}$ & Blyanter \\
\hline 20 & S6, L1, T1 & $\begin{array}{l}\text { "Bjarne Reuter: } \\
\text { 7.a." (Vognstoft. } \\
\text { dk, u.å.). opgaver i } \\
\text { kompendium til romanen } \\
\text { "7.a", (DL20). }\end{array}$ & & $\begin{array}{l}\text { PC'er } \\
\text { Papir + blyant } \\
\text { Læse-skrive-teknologi (LST) }\end{array}$ \\
\hline 21 & S6, L1, T2 & $\begin{array}{l}\text { "Bjarne Reuter: 7.a." } \\
\text { (Vognstoft.dk, u.å.), opgaver } \\
\text { i kompendium til romanen } \\
\text { "7.a", (DL20) } \\
\text { Ark med } \\
\text { grammatikopgaver, (DL21) }\end{array}$ & & $\begin{array}{l}\text { PC'er } \\
\text { Papir + blyant } \\
\text { LST } \\
\text { Post-it-sedler }\end{array}$ \\
\hline 22 & S7, L1, T1 & $\begin{array}{l}\text { "Kviksand" (Westergaard, } \\
\text { 2018), pædagogisk overlay } \\
\text { til romanen "Kviksand" af } \\
\text { Daniel Zimakoff, (DL 22). }\end{array}$ & & $\begin{array}{l}\text { PC'er } \\
\text { IWB }\end{array}$ \\
\hline 23 & S8, L1, T1 & $\begin{array}{l}\text { "Sms-novellen 'Efter } \\
\text { festen'" (Pedersen } \\
\text { \& Tingleff, } \\
\text { u.å...), fra Danskfaget. } \\
\text { dk (Clio) om SMS-novellen } \\
\text { "Efter festen" af Reneé T. }\end{array}$ & & $\begin{array}{l}\text { PC'er } \\
\text { IWB } \\
\text { Mobiltelefon }\end{array}$ \\
\hline
\end{tabular}




\begin{tabular}{|c|c|c|c|}
\hline 24 & S8, L1, T2 & $\begin{array}{l}\text { "Sætninger" (Hagen, u.å.). } \\
\text { fra. Dansk.Gyldendal. } \\
\text { dk, (DL24). }\end{array}$ & $\begin{array}{l}\text { PC'er } \\
\text { WB }\end{array}$ \\
\hline 25 & S8, L1, T3 & $\begin{array}{l}\text { "Allerede dengang gik } \\
\text { de til makronerne. Om } \\
\text { intertekstualitet" (May } \\
\text { \& Arne-Hansen, 2013) } \\
\text { fra Fandango } 7 \text { - Vinkler } \\
\text { på dansk, (DL19b). } \\
\text { Grammatip.dk (DL16b). }\end{array}$ & $\begin{array}{l}\text { PC'er } \\
\text { IWB }\end{array}$ \\
\hline 26 & S8, L1, T4 & $\begin{array}{l}\text { "Allerede dengang gik } \\
\text { de til makronerne. Om } \\
\text { intertekstualitet" (May } \\
\text { \& Arne-Hansen, 2013) } \\
\text { fra Fandango } 7 \text { - Vinkler } \\
\text { på dansk, (DL19b). }\end{array}$ & $\begin{array}{l}\text { PC'er } \\
\text { IWB }\end{array}$ \\
\hline
\end{tabular}

Note: I anden kolonne står S for skole, L for lærer, T for time. S1, L1, T1 betyder således, at casen er fra skole 1, indeholder undervisning med lærer 1 på skole 1 og at det er den første af vores observerede lektioner med denne lærer. I kolonnen med didaktiske læremidler har vi tildelt læremidlerne fortløbende numre (for eksempel DL1). Hvis flere forskellige lærere har anvendt samme didaktiske læremiddel markeres det med bogstaver (for eksempel DL1a). 